\title{
Spatial scale of cyanobacterial blooms in Old Providence Island, Colombian Caribbean
}

\section{Mónica Puyana $^{1 凶}$, Alberto Acosta ${ }^{2}$, Katherine Bernal-Sotelo $^{3}$, Trigal Velásquez-Rodríguez ${ }^{2}$, Freddy Ramos ${ }^{4}$}

\begin{abstract}
Cyanobacterial blooms have increased in coastal waters worldwide, facilitated by excessive nutrient input and apparently global warming. They exert negative consequences in marine ecosystems, communities and habitats. Although reports of these events are frequent, their spatial extent and affected habitats are not completely recognized, hence restricting regional management actions. We examined the presence, spatial scale and cover of cyanobacterial blooms in different habitats of the reef systems off Old Providence Island, and identified the main bloom forming taxa. Cyanobacteria were registered in four different ecosystems, six geomorphological zones and nine habitats. Benthic cyanobacteria reached 18 to $72 \%$ of the total cover in five habitats, particularly at the northwest, east and southeast portions of the island. These blooms consisted of complex consortia belonging to the genera Okeania, Lyngbya, Symploca, Phormidium, Oscillatoria or Spirulina. A bloom of planktonic cyanobacteria was dominated by Trichodesmium and developed on the fore reef of the island (NW), following heavy rains. These results suggest a potential new stressor for the island's reef complex. Future research should focus on the environmental factors that enable cyanobacterial blooms and their local impact on ecosystems and services.
\end{abstract}

Keywords: cyanobacteria; geomorphological zones; habitat; microbial consortia; reef system; Caribbean.

Edited by Luz Teresa Valderrama $\square$

\footnotetext{
1. Programa de Biología Marina, Departamento de Ciencias

Biológicas y Ambientales, Facultad de Ciencias Naturales e Ingeniería,

Universidad Jorge Tadeo Lozano, Bogotá, Colombia.

2. Unidad de Ecología y Sistemática, Departamento de Biología,

Facultad de Ciencias, Pontificia Universidad Javeriana.

3. Programa Regional de Posgrado en Biología, Universidad de Costa

Rica, 11501-2060 San Pedro, San José, Costa Rica.

4. Universidad Nacional de Colombia, Departamento de Química, Facultad de Ciencias, Bogotá, Colombia.
}

Received: 01-07-2014 Accepted: 20-08-2014

Published on line: 25-08-2014

Citation: Puyana M, Acosta A, Bernal-Sotelo K, Velásquez-Rodríguez

T, Ramos F (2015) Spatial scale of cyanobacterial blooms in Old

Providence Island, Colombian Caribbean. Universitas Scientiarum 20(1):

83-105 doi: 10.11144/Javeriana.SC20-1.sscb

Funding: Pontificia Universidad Javeriana; Colciencias; Universidad Jorge Tadeo Lozano; Banco de la República; Fundación Mariano Ospina Pérez-ICETEX; Universidad de Costa Rica; GeoEye Foundation-Imagery.

Electronic supplementary material: Suppl. 1 (video -planktonic bloom)

\section{Introduction}

In the Caribbean region, at least $80 \%$ of the total coral cover has been lost since the seventies (Mumby \& Steneck 2008). Factors that explain this loss are coastal development and increased human population, sewage runoff, sediment input, eutrophication, overfishing and alteration in food chains, proliferation of fleshy and turf algae (McCook et al. 2001, Burke \& Maidens 2004, Hughes et al. 2010, Vermeij et al. 2010), diseases and climate change (Aronson \& Precht 2006, Mora 2008). Reef degradation is a consequence of reduction in coral cover and coral recruitment, as well as an increase in substrate colonization by macroalgae and cyanobacteria (River \& Edmunds 2001, Kuffner \& Paul 2004, Kuffner et al. 2006, Hughes et al. 2010, Rasher \& Hay 2010, Vermeij et al. 2010, Charpy et al. 2012). 
Blooms of benthic cyanobacteria appear to be on the rise on a global scale (Paul 2008, Paerl \& Paul 2012). There are reports of these events in the Pacific Ocean (Becerro et al. 2006, Smith et al. 2008), Micronesian atolls and Hawaiian Islands (Kuffner et al. 2006), the Indian Ocean (Charpy et al. 2012), the Baltic Sea (Paerl 2002, Conley et al. 2009), and the Atlantic Ocean (Hayes et al. 2001, Paul et al. 2005).

Cyanobacterial blooms often develop in coastal zones with significant nutrient input (reviewed in Ahern et al. 2008, Paerl \& Huisman 2009) as well as in highly populated and degraded areas (Hawser et al. 1992, Butler 1995, Ritson-Williams et al. 2005). However, there are also reports of these events in isolated places such as the Fijian Islands (Yamamuro 1999), Guam (Pennings et al. 1997, Nagle \& Paul 1998, Thacker \& Paul 2001, Becerro et al. 2006) and French Polynesia (Charpy et al. 2012). Besides occurring in shallow waters, factors such as high temperature, low wave action, increased nitrogen, phosphorus, and iron availability are related to bloom formation (O'Neil et al. 2000, Kuffner \& Paul 2004, Albert et al. 2005, Ahern et al. 2007b, Ahern et al. 2008). While the causes for CyanoHABs (harmful algal blooms) in fresh and brackish waters have been thoroughly studied (reviewed in Paerl et al. 2011, Leão et al. 2012, Paerl \& Paul 2012), blooms of marine cyanobacteria are less understood.

Many species of freshwater and marine cyanobacteria have been involved in harmful algal blooms (Cyano-HABs) (Havens 2008, Paerl \& Paul 2012). These have direct or indirect negative consequences in planktonic and/or benthic communities, but in particular in organisms they have close contact with (Hallock 2005). In those events, cyanobacteria grow on the substrate, forming mats that affect benthic organisms (Ritson-Williams et al. 2005). Toxins produced by bloom-forming cyanobacteria can also affect sea turtles, mammals (including humans), fishes or invertebrates due to their neurotoxic, cytotoxic or hepatotoxic effects (Sivonen 1996, Sellner 1997, Chorus \& Bartram 1999, Metcalf \& Codd 2004, Arthur et al. 2008, Humpage 2008, Miller et al. 2010). They also exert a negative impact, as a result of chemical processes such as accumulation and liberation of hydrogen sulfide in microbial mats or oxygen consumption as blooms recede and decompose (Hallegraeff 1993, FriasLopez et al. 2003, Havens 2008). Cyanobacterial blooms affect aquatic communities at various scales (Sellner 1997), competing for light, resources, or substrate (Sivonen 1996, Huisman \& Hulot 2005). In coral reefs, cyanobacteria may play similar roles to those of macroalgae in terms of primary production and interactions with herbivores, given their local and seasonal abundance (Paul et al. 2001). For the aforementioned reasons, blooms are considered an important event in reef areas and consequently, there is a strong need to provide basic information on cyanobacteria to reef managers.

Cyanobacteria have fast growth rates and are unpalatable to most generalist herbivores (Thacker et al. 1997, Nagle \& Paul 1999, Thacker \& Paul 2004, Kuffner et al. 2006, Paerl et al. 2011, Paul et al. 2011), thus achieving high biomass (Ritson-Williams et al. 2005) and covering large areas in different marine ecosystems and habitats in periods of few weeks. Cyanobacterial blooms are seasonally recurrent in reef areas (Paul et al. 2001, Kuffner \& Paul 2004, RitsonWilliams et al. 2005, Kuffner et al. 2006), seagrass meadows (Paerl 2002, Pittman \& Pittman 2005, Conley et al. 2009), mangroves (Paerl 2002, Pittman \& Pittman 2005), estuaries and coastal lagoons (Charpy et al. 2012). In the literature however, there are few detailed descriptions of the presence and coverage of benthic cyanobacteria among different habitats in reef complexes.

Currently, there is a major concern that large scale hydrological disturbances and environmental changes due to global warming facilitate development, frequency, dispersion and expansion of cyanobacterial blooms (Albert et al. 2005, Paerl \& Huisman 2008, Paul 2008, Paerl \& Huisman 2009). Herein, we report the occurrence of cyanobacteria blooms in Old Providence Island, in order to address their spatial scale, the habitats where they develop and the extent they achieve in different marine habitats. We provide the first detailed marine habitat map for the island and include some information on the main bloom forming taxa in the region. Understanding the incidence, spatial distribution and extension of cyanobacterial blooms may help to propose monitoring and management measures in the Caribbean region. 


\section{Materials and methods}

\section{Study area}

Old Providence Island is part of the Archipelago of San Andrés, Old Providence and Santa Catalina, a group of oceanic islands, submerged banks and atolls located approximately $300 \mathrm{~km}$ off the Mosquito coast of Nicaragua (CORALINA-INVEMAR 2012, Bolaños \& Acosta 2013). The archipelago is part of the Seaflower Biosphere Reserve established by UNESCO in 2000, a protected area that encompasses roughly $10 \%$ of the Caribbean Sea.

Old Providence is an island of volcanic origin (Miocene), with an emerged area of $20 \mathrm{~km}^{2}$. The shallow reef complex in Old Providence has a total area of $285 \mathrm{~km}^{2}$ and is characterized by the development of different coral formations (Geister 1977, 1986, Díaz et al. 2000). A $32 \mathrm{~km}$ long reef barrier runs along the eastern side of the island (García et al. 2003). The dominant associations in the barrier are associations of milleporids and zoanthidians (in the barrier reef and pinacles), patch reefs where predominant taxa are Montastraea spp., Porites astreoides and Diploria spp. and fringing reefs surrounding Kathleena island (Santa Catalina) and the northeast portion of Old Providence. These are characterized by massive corals such as Siderastrea siderea, Diploria spp. and Montastraea spp., along with Porites spp. On the western side of the island, the fore-reef terrace is characterized by the dominance of octocorals, macroalgae and corals such as Dendrogyra cylindrus (Acosta \& Acevedo 2006), Porites spp. and Diploria spp. (Sánchez 1998, Díaz 2005, Acosta et al. 2011, Bernal-Sotelo \& Acosta 2012).

The archipelago has a wet-dry tropical climate, with two major weather seasons: dry (January to April) and wet (June to December), with maximum peaks of rain between October and November (266-301 mm) (González \& Hurtado 2012). May is considered a transitional month between seasons (Díaz et al. 1996). The warmer months of the year range between May to late September (Vivas-Aguas et al. 2012). Water temperature varies between $28.2^{\circ} \mathrm{C} \pm 1.26 \mathrm{SD}$ (Range: 24-32 ${ }^{\circ} \mathrm{C}$; Vivas-Aguas et al. 2012). Surface salinity shows average values of $34.8 \pm 1.62$ (Range: 26-37; Vivas-Aguas et al. 2012). Variations in temperature and salinity between the dry and wet seasons are mostly related to precipitation levels (INVEMAR-REDCAM
2013). It also receives seasonal discharge of fresh water streams (sediments and organic matter input) from the island outwards to the sea (Geister \& Diaz 1997).

Prevailing winds from the east and northeast (influence of the northeast trade winds) divide Old Providence Island in a dry eastern side and a western humid side. The months with low current action due to decreased wind speed are May, September and October (Realpe et al. 2012, González \& Hurtado 2012). Tides are semi-diurnal but narrow. The western portion of the island is occasionally affected by strong swells.

In the archipelago, nitrate and phosphate concentrations exhibit great variation, with high values surpassing those of other Caribbean locations. Nutrient concentrations vary depending on sites, time of the year and distance to human dwellings (Gavio et al. 2010). In Old Providence island, greater nutrient levels during the wet season are correlated with increased fresh-water runoff by temporary streams or gullies, untreated sewage discharge, landfill leachates, organic and inorganic residues from animal husbandry practices and mangrove leaf litter inputs from the Mc Bean Lagoon area (Vivas-Aguas et al. 2012). Dissolved organic nitrogen values from Old Providence island are on average $74.38 \pm 39.43 \mu \mathrm{g} / \mathrm{L}$ (Range: 2.7-281 $\mu \mathrm{g} / \mathrm{L}$ ), while phosphate concentrations are on average $88.9 \pm 183.7 \mu \mathrm{g} / \mathrm{L}$ (Range: $1.8-1352 \mu \mathrm{g} / \mathrm{L}$; Vivas-Aguas et al. 2012).

\section{Sampling}

Field surveys of cyanobacteria were performed in Old Providence Island in three moments. The first set of surveys was performed during the rainy months of October-November 2009 and July 2010, at three reef sites at the western portion of the island (Pinnacles, Felipe's Place and El Planchón). In these surveys we evaluated the cover of benthic cyanobacteria using belt transects covering an area between 30 and $60 \mathrm{~m}^{2}$ at each site. We also registered signs such as tissue mortality, overgrowth or direct competition between corals, gorgonians and cyanobacteria. The second set of surveys was performed between OctoberNovember 2012. In these, a detailed assessment of benthic and planktonic cyanobacterial blooms on different substrates at the shallow reef complex of Old Providence, between 1 and $15 \mathrm{~m}$ depth, was carried out 
(Figure 1). In these surveys, a Quickbird Satellite image from 2012 was used to identify and locate habitats and their main benthic components. The satellite image domain $\left(13^{\circ} 18^{\prime}-13^{\circ} 24^{\prime} \mathrm{N}\right.$ and $\left.81^{\circ} 19^{\prime}-81^{\circ} 25^{\prime} \mathrm{W}\right)$ was processed by georeference with field data. Atmospheric correction was performed using the module FLAASH

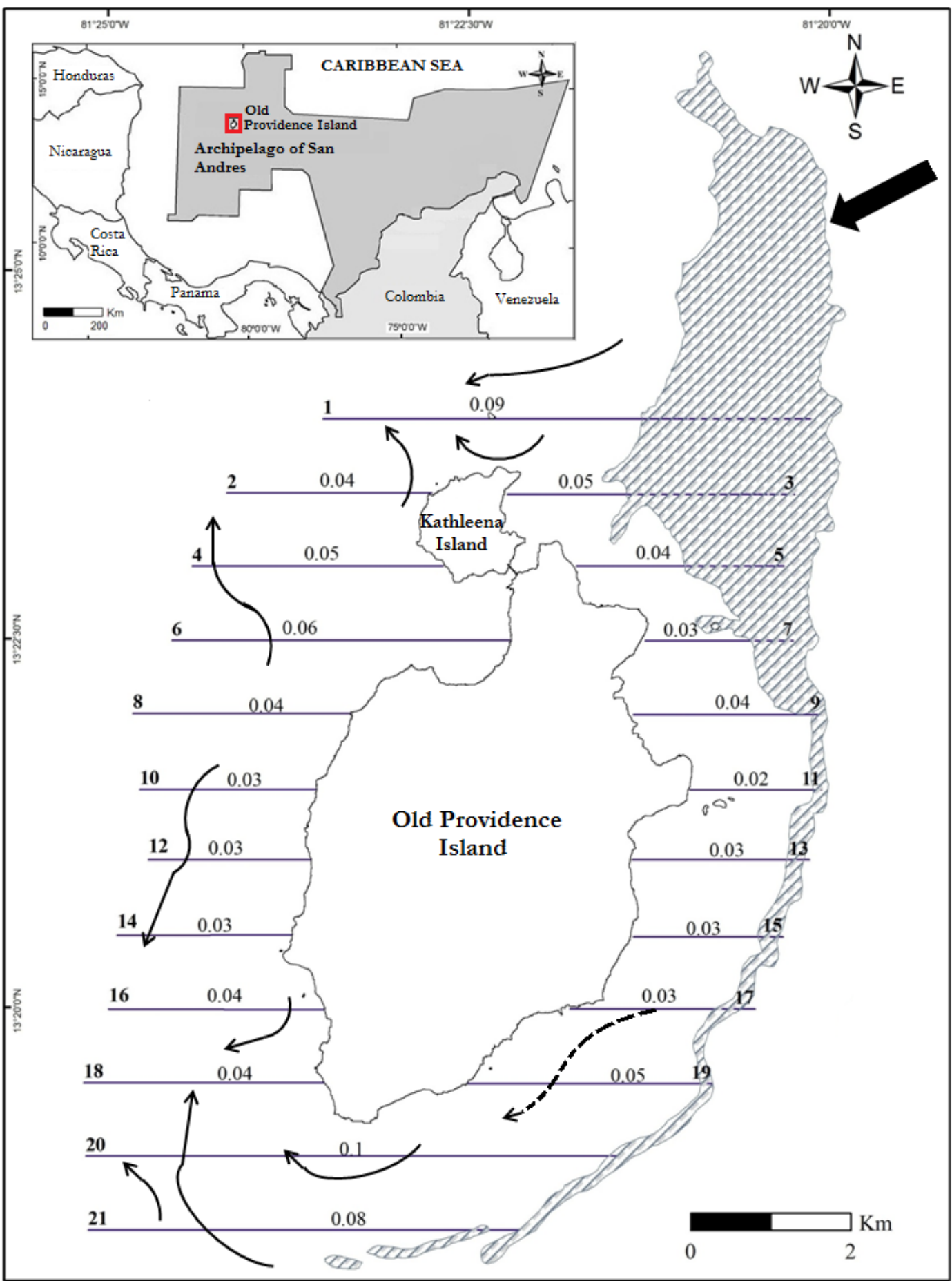

Fig. 1. Study area sampled at Old Providence Island during October 2012. Straight lines around the island represent the sampling transects evaluated by Manta Tow. Bold numbers at the beginning of each transect indicate transect number. Values in the middle of each line show the sampling area of each transect in $\mathrm{km}^{2}$. All transects had the same width $(0.015 \mathrm{~km})$, but length was variable (transect $1=6 \mathrm{~km}$, transect $20=7 \mathrm{~km}$, transect $21=5 \mathrm{~km}$, transects 3 and $6=4 \mathrm{~km}$, transects $2,4,5,8,16,18$ and $19=3 \mathrm{~km}$, transects 7, 9, 10,11,12,13,14,15, transect $17=2 \mathrm{~km}$ ). Striped areas along the east portion of the island represent the barrier reef. Bold black arrows show the general pattern of marine currents around the island (Prahl 1983). Map system projection is WGS84. 
ENVI 5.0 and deglint following Hedley et al. (2005). Application of Lyzenga's (1981) depth invariant index, allowed reducing the interference from the water column and its variable depth following Mumby and Edwards (2000). Twenty one, $15 \mathrm{~m}$ wide transects, perpendicular to the coast, were examined to register cyanobacteria presence and relative coverage. Transects were separated from each other by roughly $930 \mathrm{~m}$ (30 s; Fig. 1). Transect length varied depending at which side of the island they were placed. Transects on the western side of the island spanned from the shore until the beginning of the reef slope ( $<15 \mathrm{~m}$ depth), whereas transects on the eastern side of the island spanned from the shore until the beginning of the barrier reef. The Manta Tow technique was applied along each transect, where two divers were tethered to the boat with a 10 $m$ rope and towed over the water surface at a speed of 1-2 knots. Within each transect, we recorded the type and frequency of the different habitats observed and estimated the relative area covered by cyanobacteria. We also recorded and geopositioned $( \pm 3 \mathrm{~m}$ ), the beginning and the end of each habitat type along each transect. Hence, the extent of each habitat category in the space was considered a "point". All habitat types, reordered in the sampling, were later used to classify and validate the satellite image (Bernal et al. unpub. data). We registered a total of 550 points that covered different habitat types. Each habitat category was defined by the type and relative cover of its most prominent benthic components, including cyanobacteria. Occasionally, either water depth or turbidity impeded an adequate identification of the main benthic components, so divers descended to take either pictures or samples to correctly identify those features. We recorded blooms either by underwater photographs or video footage (Suppl. 1).

Habitats were classified according to the relative coverage of benthic components following similar studies in the region (Díaz et al. 2000, Benfield et al. 2007, Madden et al. 2008, Walker et al. 2008). Each unit was labeled by initially naming the geomorphologic area where it was located (Figure 2), followed by abbreviations of the main benthic components according to their relative dominance (higher to lower). Components with coverage $\leq 5 \%$ were excluded from the habitat label. When elements had similar coverage (difference $\leq 3 \%$ ), the elements were

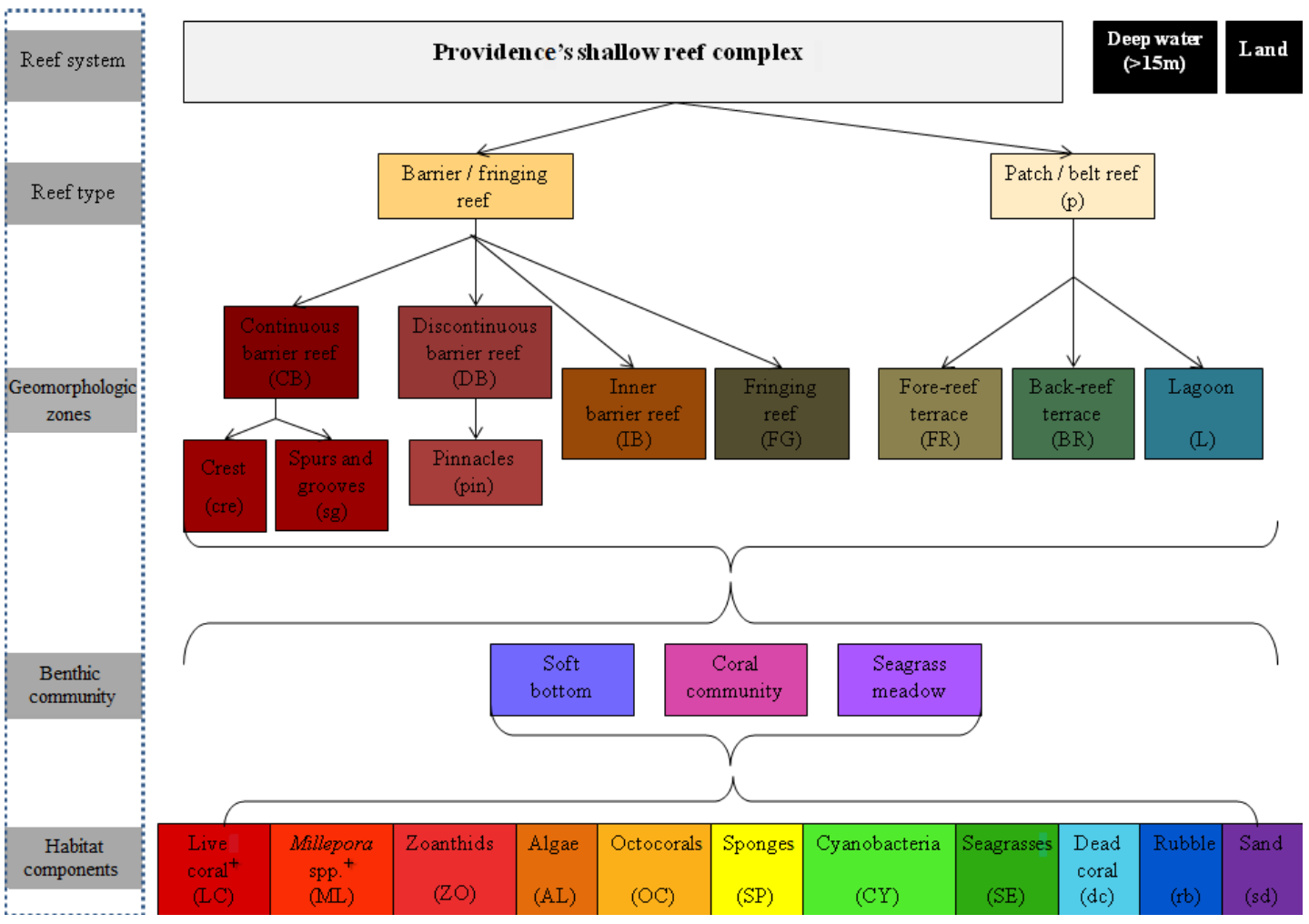

Fig. 2. Scheme of the reef classification, geomorphological zones, benthic communities and components used to categorize and name habitats in the Old Providence Island reef complex. 
separated by a hyphen (-), always placing the dominant element in first place. Habitats with presence but very low live coral cover $(\leq 5 \%)$ were marked with an asterisk $(*)$. The image was segmented into objects using Berkeley Image Segmentation software. Then, each segment was assigned to a category of habitats, following field surveys, visual interpretation of the image and the pattern of spectral signatures. The image was then validated with 152 points referenced in the field (following Chuvieco 2008), resulting in an overall accuracy of $94 \%$ and a 0.94 Kappa coefficient (Mumby \& Edwards 2000). Finally, we generated a map of the habitats where cyanobacteria were found as well as the area $\left(\mathrm{km}^{2}\right)$ occupied by each unit and the area occupied by cyanobacteria within the unit.

Additionally, we used DIVA-GIS 7.4.0 software to generate a map representing the frequency in which cyanobacteria were recorded in georeferenced field points. The map was divided into spatial cells of $270 \mathrm{x}$ $270 \mathrm{~m}\left(0.073 \mathrm{~km}^{2}\right)$ in which we identified cyanobacteria density or the number of points with cyanobacteria (absolute record frequency). Each cell was identified with a specific color according to the frequency of points (white $=0$ points, blue $=1$ point, turquoise $=$ 2 points, yellow $=3$ points; red $=4$ points, where the minimum registered value per cell was 0 points and the maximum registered value per cell was 4 points).

The third set of surveys was performed during December2012. In these, we assessed the accumulation of drifting cyanobacteria on Old Providence beaches.

We do not perform long term assessments of environmental parameters such as nutrients, salinity or temperature in any of our surveys. During underwater surveys, a small sample of cyanobacterial mats (10 to $20 \mathrm{~g}$ ) was collected and preserved in 4\% formalin in seawater, to identify the main bloom forming species. To identify the different cyanobacterial morphotypes, three portions of each sample were analyzed under a Nikon optical microscope. The microscope was connected to a digital camera. The captured images were analyzed using NIS-Elements Br 2.30 Nikon Imaging Software, which allows performing the necessary measurements of each morphological attribute under several magnifications up to 100X. Characters considered for species identification were trichome width, cell length, presence of calyptrae, filament isopolarity, shape of apical cells, presence of intertabicular constrictions and presence of mucilaginous cases (Komárek \& Anagnostidis 2005). Taxonomic identification of cyanobacteria has been traditionally performed on the basis of morphological parameters, especially in those belonging to the order Oscillatoriales due to their large cell size (Thacker \& Paul 2001, Charpy et al. 2010, Engene et al. 2010). For the purposes of this paper we report the most common taxa found during field surveys after Komárek \& Anagnostidis (2005) and Engene et al. (2013b). During the period between 2011 and 2014 there has been a profound reevaluation of the group systematics beyond genera reassignment, showing great genetic diversity, and wide morphological and chemical variation (Thacker \& Paul 2004, Engene et al. 2010, Engene et al. 2011, Engene et al. 2012, Engene et al. 2013a, Engene et al. 2013b). Blooms of marine benthic cyanobacteria are not monospecific and "accurate" species identification involves molecular and chemotaxonomical analyses. However, there are still many sequences that can only be resolved at a genus level. Therefore, a species list of bloom forming cyanobacteria with their mean abundances or maps indicating their spatial distribution was not performed.

\section{Data analysis}

Data coverage (\%) of each benthic component, as well as the coverage of benthic cyanobacteria $\left(\mathrm{km}^{2}\right)$, were compared between habitats applying the nonparametric Kruskal-Wallis test since data did not adjust to a normal distribution (Kolmogorov-Smirnov test for coverage data: $\mathrm{n}=184, \mathrm{p}<0.05$ and ShapiroWilk test for area occupied by cyanobacteria: $n=9$, $\mathrm{p}<0.05$ ), or were not homoscedastic (Levene test for coverage and area: $n=184$ and $n=9, p<0.05)$.

\section{Results}

Cyanobacterial mats were complex microbial consortia always composed by several cyanobacteria "species" (Figure 3). The most frequent mats were dominated by Okeania cf. erythroflocculosa (Engene et al. 2013b) and appeared as thick red mats overgrowing sand, rubble and macroalgae over hard substrates. We also found a great abundance of thick, puff-like mats composed by Symploca bydnoides (Kützing ex Gomont 1892) and Phormidium submembranaceum (Ardissone et Straforello 1877 ex Gomont 1892). Those mats were particularly abundant 

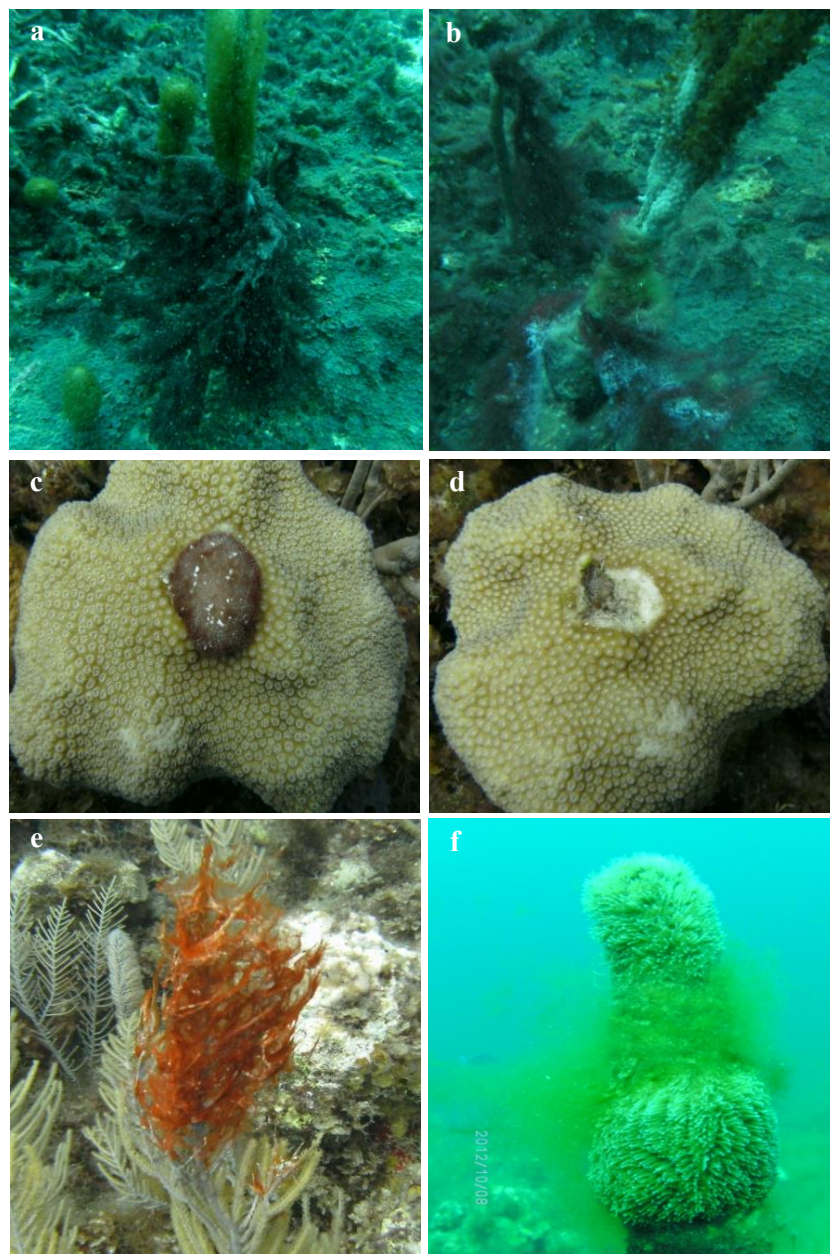

Fig. 3. (a, b) An assemblage of Okeania spp. overgrowing the base of a sea rod Eunicea sp. Bleaching and tissue damage became apparent after the cyanobacterial mat was removed. (c, d) An assemblage of Symploca bydnoides and Phormidium submembranaceum growing over a Montastrea franksi colony. Tissue death was evident after the cyanobacterial mat was removed. (e) Red encrusting biofilms (assemblages of Oscillatoria spp., Phormidium gracile and Lyngbya spp.) rapidly overgrew gorgonian corals exposing the gorgonin matrix which was rapidly fouled. (f) Drifting mats of Trichodesmium entangled in a Dendrogyra cylindrus column. Prolonged contact with cyanobacteria caused bleaching and signs of white syndromes in the coral.

at the Pinnacles NE of the island and developed over the locally abundant Turbinaria and Dictyota macroalgae. Thin red or brown films were very common over well illuminated sandy substrates. These mats were composed by complex assemblages of Oscillatoria spp., Lyngbya spp. and Phormidium spp. in varying proportions. On the other hand, vertical mats growing under ledges or large corals, were only found at the Pinnacles NE of the island.
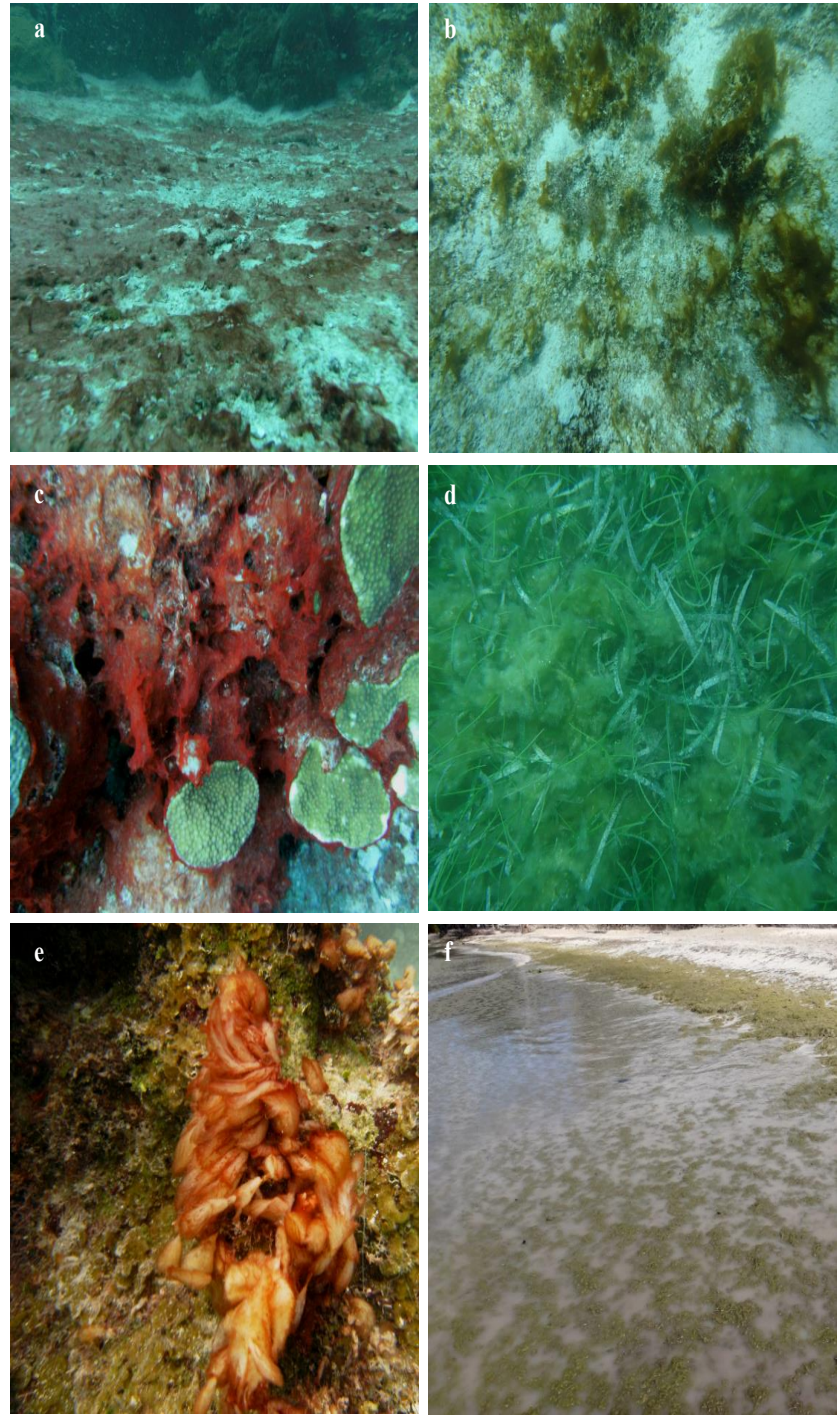

Fig. 4. Ecosystems and habitats in the Old Providence Island reef complex with extensive cyanobacteria cover (a) sandy bottoms, (b) calcareous algae and sand, (c) coral dominated reefs (d) Seagrasses (Thalassia-Syringodium), (e) macroalgae over dead coral, (f) accumulation of cyanobacteria at Southwest Bay beach after a threeday period of storms in November 2012. (Photo: Jim Robinson Martinez) The event also took place in December 2013.

These were composed of long red strands of Oscillatoria cf. acuminata (Gomont 1892) interspersed with few Spirulina subsalsa (Oersted ex Gomont 1892) filaments. Additionally, very thin red biofilms were sporadically found overgrowing gorgonians, displacing live tissue and exposing the gorgonin matrix (M. Puyana, unpub. data). These particular mats were complex microbial consortia of Oscillatoria spp., Phormidium (= Leptolyngbya) 


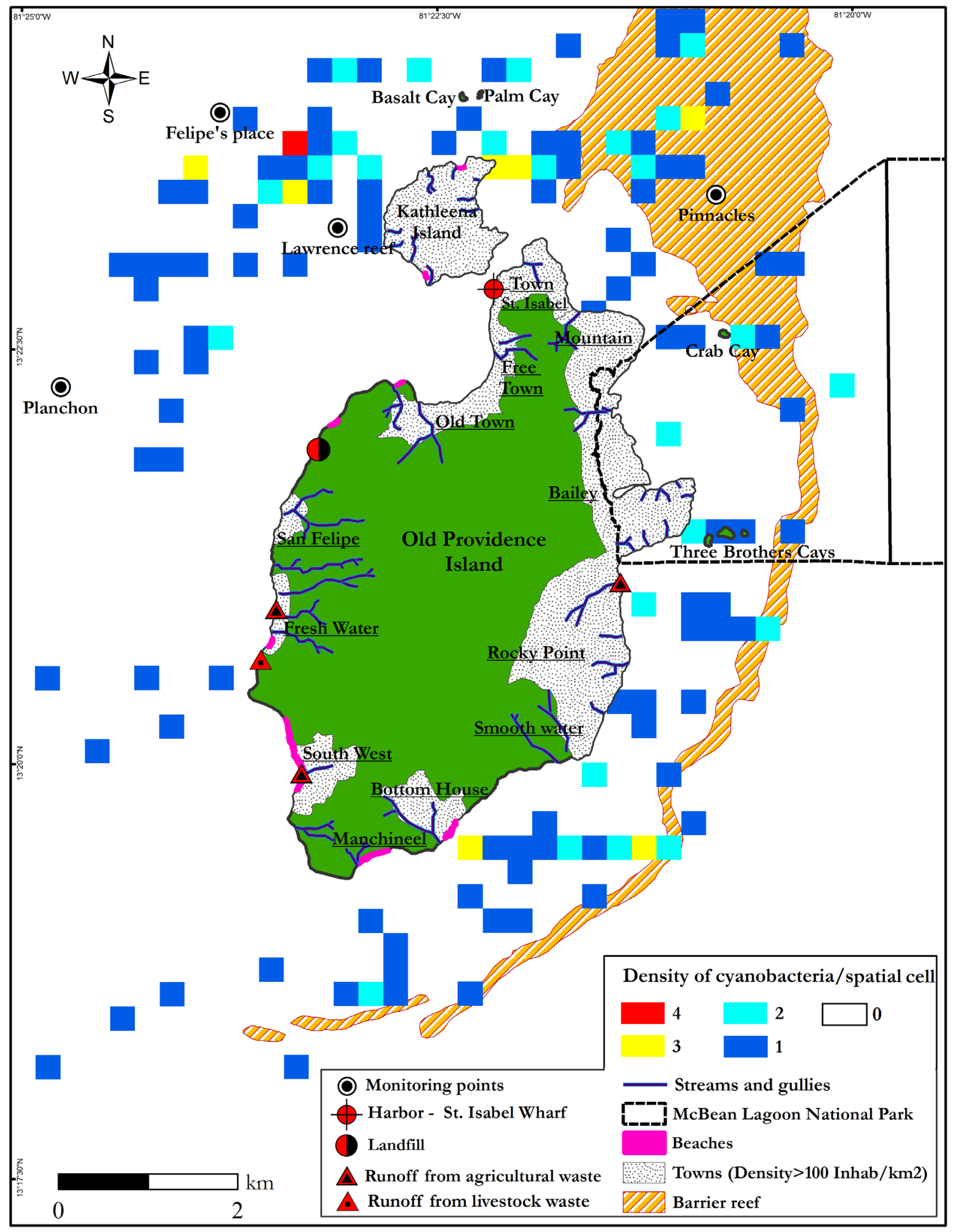

Fig. 5. Cyanobacterial density (frequency of field points) in the Old Providence Island shallow reef complex. The area was divided in $270 \times 270 \mathrm{~m}$ spatial cells $\left(0.073 \mathrm{~km}^{2}\right)$. Note red and yellow spatial cells (north-west) with the greatest number of sampling points with presence of cyanobacteria. In white spatial cells, cyanobacteria were not recorded. Main pollution sources are shown following Vides \& Sierra-Correa (2003): Streams and gullies, population density of main towns, harbor, landfill and runoff sources from livestock and agricultural waste activities. Names of the main towns are underlined. The borders of the Old Providence McBean Lagoon National Park are indicated in the map. Monitoring sites from 2009 to 2010 are also shown. 


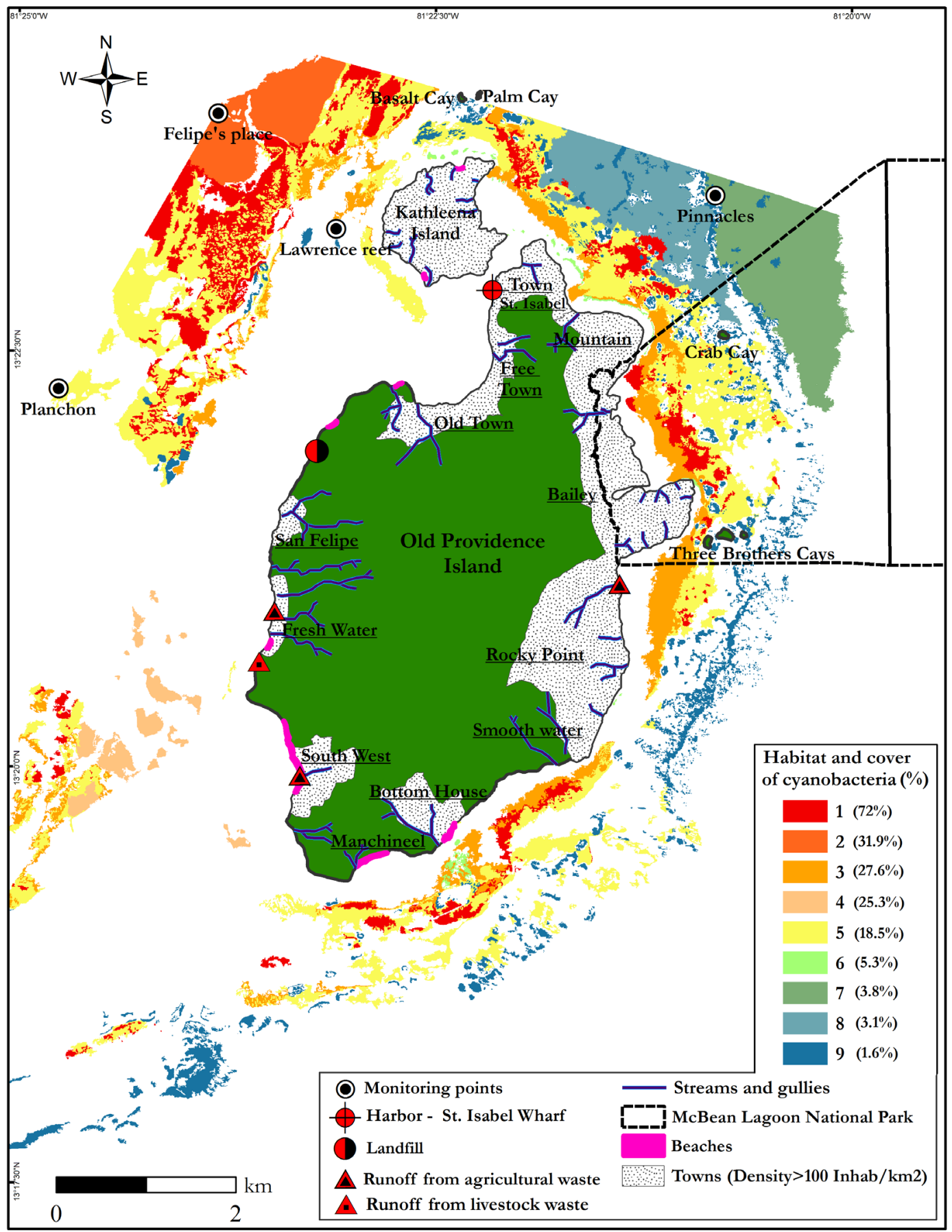

Fig. 6. Spatial distribution and cyanobacteria cover in different marine habitats in the Old Providence Island shallow reef complex. Note that the island was surrounded by cyanobacteria, but with the highest cover (red to yellow spatial cells) towards the north-west and north east portions. Numbers from 1 to 9 represent habitat code organized from those with highest (1) to lowest (9) cyanobacteria cover. Total benthic cyanobacteria cover $>15 \%$ was considered high. Habitats: 1. FR-BR-L: Cyanobacteria and sand. 2. FR: Cyanobacteria, algae-dead coral and mixed coral-octocoral-sand. 3. L: Seagrasses, cyanobacteria and sand. 4. L: Sand, cyanobacteria and octocoral. 5. FR-BR-L: Sand and cyanobacteria. 6. FG-Lp: Algae, mixed coral, seagrass and dead coral-sand. 7. DBpin: Algae, sand and dead coral-Palythoa spp.-M. complanata*. 8. Lp: Sand, algae and dead coral*. 9. BRp-Lp: Algae and sand-dead coral-rubble*. BR=Back-reef terrace. BRp=Patch reef of the back-reef terrace. DBpin=Pinnacles of the discontinuous barrier reef. FG=Fringing reef. FR=Fore-reef terrace. FRp=Patch reef of the fore-reef terrace. L=Lagoon. Lp=Patch reef of the lagoon. Habitats marked with an asterisk $\left(^{*}\right)$ had a live coral cover $\leq 5 \%$. Main pollution sources are shown following Vides \& Sierra-Correa (2003): Streams and gullies, population density of main towns, harbor, landfill and runoff sources from livestock and agricultural waste activities. Names of the main towns are underlined. The borders of the Old Providence McBean Lagoon National Park are indicated in the map. 
gracile (Meneghini ex Gomont, Anagnostidis 2001) and occasionally Lyngbya spp. Field surveys revealed signs of coral bleaching or tissue necrosis upon direct contact between benthic cyanobacteria and hard and soft corals (Figure 3). Moreover, the complex assemblages of thin red biofilms overgrowing gorgonians displaced live tissue, leaving behind the exposed gorgonin matrix, which was in turn rapidly fouled by algae and hydroids (Figure 3).

In late October 2012 (wet season), we recorded a massive shallow (1-15 m) bloom of planktonic cyanobacteria (Suppl. 1) and ctenophores at the NW portion of the island $\left(13^{\circ} 22^{\prime} 47.8^{\prime \prime} \mathrm{N}-81^{\circ} 23^{\prime} 57.3^{\prime \prime} \mathrm{W}\right)$. Unlike previous findings (Quintana 2011; Prato 2013) the bloom thrived at various levels in the water column (calm water, no currents) considerably hindering horizontal visibility $(<15 \mathrm{~m})$. The bloom accumulated as thick $(40 \mathrm{~cm})$ drifting mats over the reef bottom (Suppl. 1) and by November 2012, it had spread over a large area. Microscopical analyses revealed that the bloom was dominated by Trichodesmium interspersed with some Lyngbya filaments. Dendrogyra corals were affected by these planktonic blooms (Figure 3). As cyanobacterial mats drifted over the corals, they got entangled in the column structure and promoted the onset of white syndromes and partial death.
In Old Providence Island blooms of benthic and planktonic cyanobacteria developed in four ecosystems: benthic blooms over sandy bottoms, seagrasses and coral reefs (Figure 4), and planktonic blooms in the pelagic zone (Suppl. 1). Benthic cyanobacteria were also present in six geomorphological zones (Back-reef terrace, Patch reefs, Pinnacles, Fringing reefs, Forereef terrace and Lagoon) and nine habitats. While the planktonic bloom occurred only in the Fore-reef terrace and in one habitat (FR: cyanobacteria -60\%, dead coral $-30 \%$, and live mixed coral $10 \%$ cover).

The presence of benthic cyanobacteria was observed all around the island (Figure 5). Those blooms were more prevalent at the NW portion of the island (Felipe's Place, Lawrence Reef and El Planchón; Figure 5), where the highest live coral cover remains $14.1 \pm 3.9 \%$ on average. Only $6.3 \%$ of the spatial cells had high densities of cyanobacteria (3 or 4 points with cyanobacteria; $5.5 \%$ with three points, $0.8 \%$ with four points), mainly in the $\mathrm{N}$ portion of the island, where most spatial cells $(270 \times 270 \mathrm{~m})$ had 3 or 4 points with cyanobacteria (Figure 5). Most (> 90 \%) spatial cells; however, had low cyanobacteria density (between 1 and 2 points where cyanobacteria were present: $74 \%$ with one point, $19.7 \%$ with two points; total cells with cyanobacteria $=127$; Figure 5).

Table 1. Relative cover of benthic cyanobacteria and total area sampled in marine habitats at Old Providence Island shallow reef complex. Symbols represent the habitat code assigned in maps and other figures. Habitats were organized from those with highest (1) to lowest (9) cyanobacteria cover. Habitats marked with an asterisk $\left(^{*}\right)$ had a live coral cover $\leq 5 \%$. HB=Habitat. The first letters in each habitat are abbreviations indicating the geomorphologic zones where they were located: BR=Back-reef terrace. $\mathrm{BR}=$ Patch reef of the back-reef terrace. DBpin=Pinnacles of the discontinuous barrier reef. $F G=$ Fringing reef. FR=Fore-reef terrace. FRp=Patch reef of the fore-reef terrace. $\mathrm{L}=$ Lagoon. $\mathrm{Lp}=$ Patch reef of the lagoon. Other components in the habitat names are listed in descending order of benthic coverage.

\begin{tabular}{|c|c|c|c|c|c|}
\hline Symbol & Habitat & $\begin{array}{c}\text { Depth } \\
\text { interval (m) }\end{array}$ & $\begin{array}{c}\text { Total HB } \\
\text { area }\left(\mathrm{Km}^{2}\right)\end{array}$ & $\begin{array}{c}\text { Area covered by } \\
\text { cyanobacteria/ } \\
\text { HB }\left(\mathrm{km}^{2}\right)\end{array}$ & $\begin{array}{c}\text { Cyanobacteria } \\
\text { cover }(\%)\end{array}$ \\
\hline 1 & FR-BR-L:Cyanobacteria and sand & $0.4-15.3$ & 2.6 & 1.89 & 72 \\
\hline 2 & FR:Cyanobacteria, algae-dead coral and mixed coral-octocoral-sand & 3.6-15.3 & 1.1 & 0.35 & 31.9 \\
\hline 3 & L:Seagrass, cyanobacteria and sand & $0.4-13.1$ & 2.1 & 0.57 & 27.6 \\
\hline 4 & L:Sand, cyanobacteria and octocoral & $0.4-13.1$ & 0.5 & 0.13 & 25.3 \\
\hline 5 & FR-BR-L:Sand and cyanobacteria & $0.4-15.3$ & 7 & 1.29 & 18.5 \\
\hline 6 & FG-Lp:Algae, mixed coral, seagrass and dead coral-sand & $0.5-7.7$ & 0.1 & 0.01 & 5.3 \\
\hline 7 & DBpin:Algae, sand and dead coral-Palythoa spp.-M. complanata* & $0.6-8.9$ & 2.1 & 0.08 & 3.8 \\
\hline 8 & Lp:Sand, algae and dead coral* & $0.4-13.1$ & 1.6 & 0.05 & 3.1 \\
\hline \multirow[t]{2}{*}{9} & BRp-Lp:Algae and sand-dead coral-rubble* & $1.2-9.1$ & 2.1 & 0.03 & 1.6 \\
\hline & Total & & 19.2 & 4.4 & \\
\hline
\end{tabular}


Blooms of benthic cyanobacteria developed as mats that varied in extension, color and thickness. They also varied on the types of habitat they were found. A large scale analysis revealed that nine of the 25 habitats registered on the shallow reef complex of Old Providence Island, (Table 1) had a relative coverage of cyanobacteria $>1 \%$, at the fore reef $(\mathrm{NW})$, pinnacles $(\mathrm{NE})$, reef flat and lagoon $(\mathrm{E})$ of the island. The total area of these nine habitats represents $30 \%$ of the shallow reef complex, spanning an area of $64.3 \mathrm{~km}^{2}$. During cyanobacterial blooms, five of the nine habitats $(55.5 \%)$ had high cyanobacteria cover, reaching 18 to $72 \%$ of the total cover, particularly at the northwest, east and southeast portions of the island. Cyanobacteria covered over $4.2 \mathrm{~km}^{2}$ of the reef complex (from $64.3 \mathrm{~km}^{2}$ sampled; Figure 6) particularly in those habitats with low live coral cover and high coverage of sand, macroalgae, dead coral or seagrasses.

The habitat dominated by cyanobacteria that achieved the greatest extension was 5 (FRBRL: Sand and cyanobacteria; Table 1), spanning an area of $7 \mathrm{~km}^{2}$. However, the greatest cyanobacteria cover (72 \%) was registered in habitat 1 (FRBRL: Cyanobacteria and sand). This habitat was the second in extension covering an area of $2.6 \mathrm{~km}^{2}$ and spanning around the island's contour, especially towards the NW. Habitats with cyanobacteria coverage between 18 and $32 \%$ (2 - FR: Cyanobacteria, algae-dead coral and mixed coral-octocoral-sand, 5 - FRBRL: Sand and cyanobacteria), stretched around the reef complex. Habitats with cyanobacteria coverage lower than $6 \%$ (6 - FG-Lp: Algae, mixed coral, seagrass and dead coral-sand; 9 - BRp-Lp: Algae and sand-dead coral-rubble; Table 1) were registered all along the eastern side of the island, from South to North, particularly at the NE end of the complex (Figure 6). Within the protected area of McBean Lagoon National Park (PNN McBean) and its surroundings, we also detected foci with high cover of cyanobacteria (>70\%; Figure 6).

Overall, in habitats 5, 1, 3, 7 and 9 (BRp-Lp: Algae and sand-dead coral-rubble*) the area covered by cyanobacteria was $>2 \mathrm{~km}^{2}$, whereas in the other four habitats, the area covered by cyanobacteria was lower (Figure 7A; Table 1). However, there were no significant differences in the area covered by cyanobacteria within all nine habitats $(H: p>0.05$,
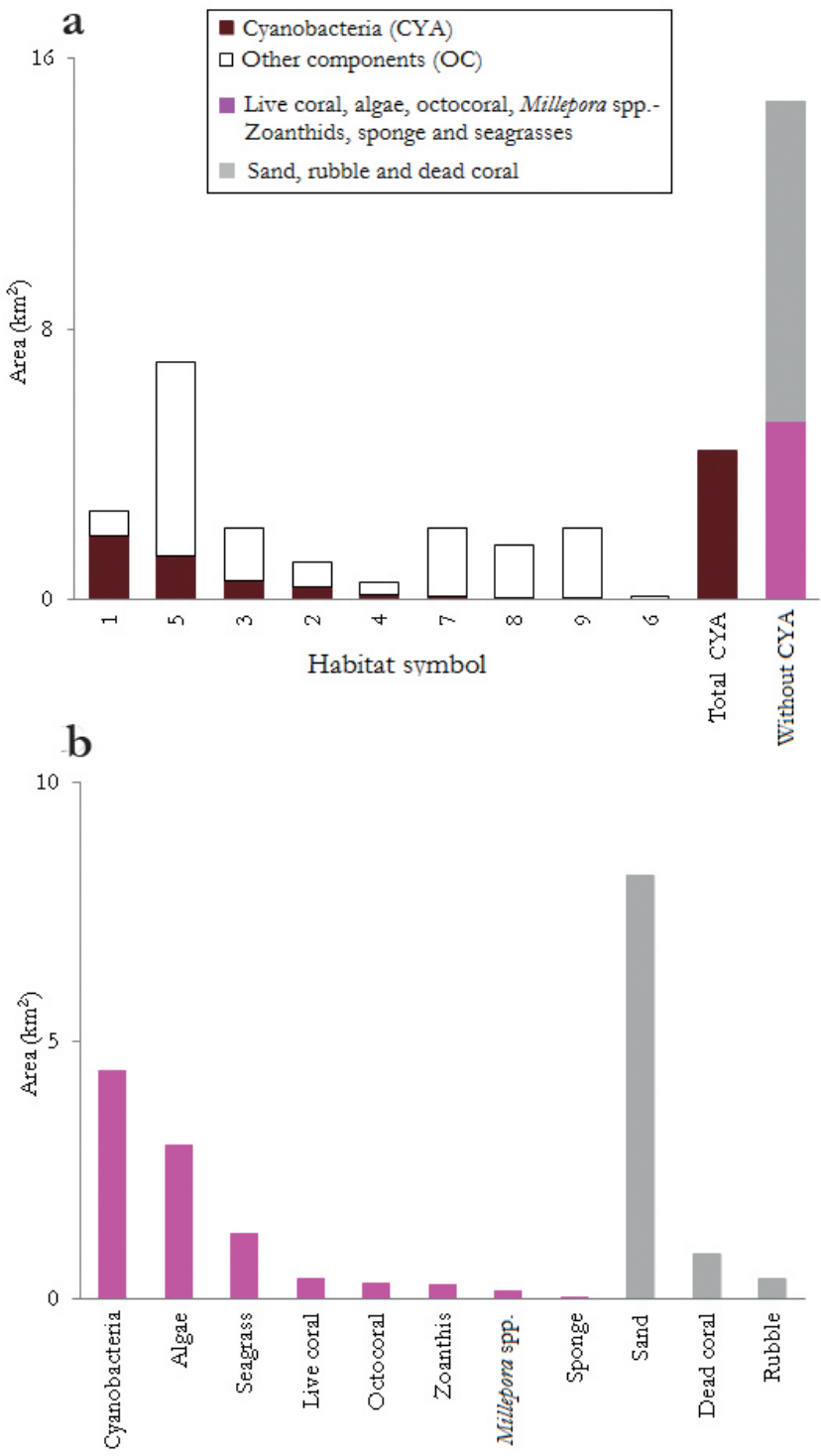

Fig. 7. (a) Total area covered by cyanobacteria in each habitat related to cover of live organisms and other substrate components. (b) Total area covered by live organisms and substrate components in all nine habitats. Other components include the sum of all organisms and substrate types. 1. FR-BR-L: Cyanobacteria and sand. 2. FR: Cyanobacteria, algae-dead coral and mixed coraloctocoral-sand. 3. L: Seagrasses, cyanobacteria and sand. 4. L: Sand, cyanobacteria and octocoral. 5. FR-BR-L: Sand and cyanobacteria. 6. FG-Lp: Algae, mixed coral, seagrasses and dead coral-sand. 7. DBpin: Algae, sand and dead coralPalythoa spp.-M. complanata* ${ }^{*}$. Lp: Sand, algae and dead coral*. 9. BRp-Lp:Algae and sand-dead coral-rubble*. $\mathrm{BR}=$ Back-reef terrace. $\mathrm{BRp}=$ Patch reef of the back-reef terrace. DBpin=Pinnacles of the discontinuous barrier reef. $\mathrm{FG}=$ Fringing reef. $\mathrm{FR}=$ Fore-reef terrace. $\mathrm{FRp}=$ Patch reef of the fore-reef terrace. $\mathrm{L}=\mathrm{Lagoon}$. $\mathrm{L}=$ Patch reef of the lagoon. 

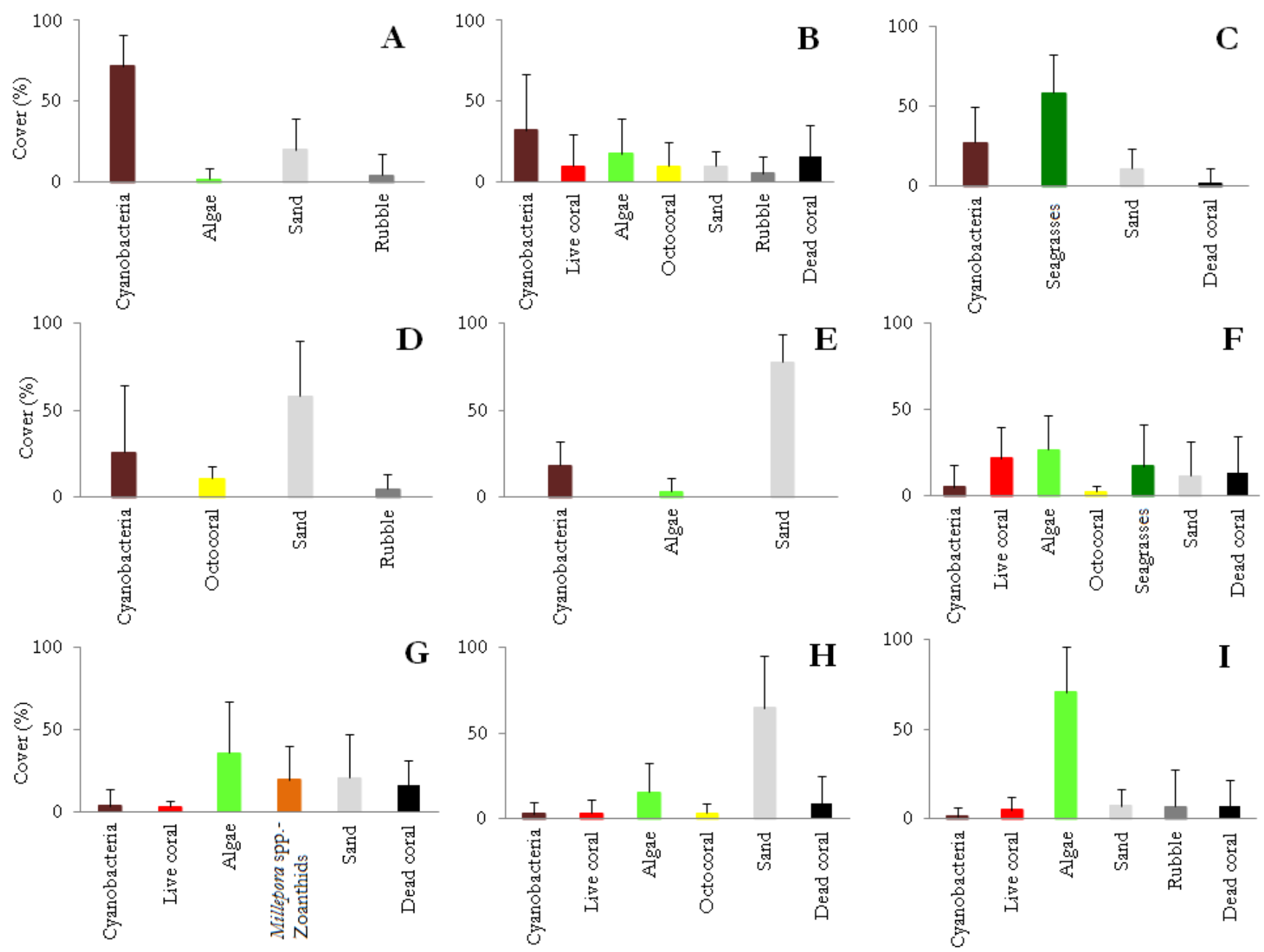

Fig. 8. Relative cover (\%) of live organisms and other substrate components in the different habitats where cyanobacteria were registered. 1. FR-BR-L: Cyanobacteria and sand (a) 2. FR: Cyanobacteria, algae-dead coral and mixed coral-octocoral-sand (b). 3. L: Seagrasses, cyanobacteria and sand (c). 4. L: Sand, cyanobacteria and octocoral (d). 5. FR-BR-L: Sand and cyanobacteria (e). 6. FG-Lp:Algae, mixed coral, seagrasses and dead coral-sand (f). 7. DBpin: Algae, sand and dead coral-Palythoa spp.-M. complanata* (g). 8. Lp: Sand, algae and dead coral* (h). 9. BRp-Lp: Algae and sand-dead coral-rubble* (i). BR=Back-reef terrace. BRp=Patch reef of the back-reef terrace. DBpin=Pinnacles of the discontinuous barrier reef. FG=Fringing reef. FR=Fore-reef terrace. $F R p=$ Patch reef of the fore-reef terrace. $L=L a g o o n . ~ L p=$ Patch reef of the lagoon.

$\mathrm{n}=9)$. Therefore, the intensity of cyanobacteria was homogeneously distributed in all nine habitats, around the island. The total area covered by cyanobacteria in all habitats $\left(4.4 \mathrm{~km}^{2}\right)$ was $0.89 \mathrm{~km}^{2}$ less than the total area covered by live organisms (algae, seagrasses, live coral, octocorals, zoanthids, Millepora and sponges; $5.3 \mathrm{~km}^{2}$; Figure 7A).

Within living components, cyanobacteria had the greatest coverage in all habitats followed by algae $\left(2.96 \mathrm{~km}^{2}\right)$ and seagrasses $\left(1.25 \mathrm{~km}^{2}\right)$. The remaining categories occupied less than $0.4 \mathrm{~km}^{2}$ each (Figure
7B). Sandy bottoms covered an area of $8.21 \mathrm{~km}^{2}$, half of it was covered by cyanobacteria (Figure 7B).

The average coverage of live components and other substrates was significantly different among all habitats $(\mathrm{H}: \mathrm{n}=184, \mathrm{p}<0.05)$. In most habitats though, categories with the greatest coverage were, aside from cyanobacteria, sand, algae, seagrasses and dead coral (Figure 8). Only in habitat 6 (FG-Lp: Algae, mixed coral, seagrasses and dead coral-sand) we registered a live coral coverage $>20 \%$ whereas in habitats 7 and 8 (7=DBpin: Algae, sand and dead coral-Palythoa spp. $-M$. 

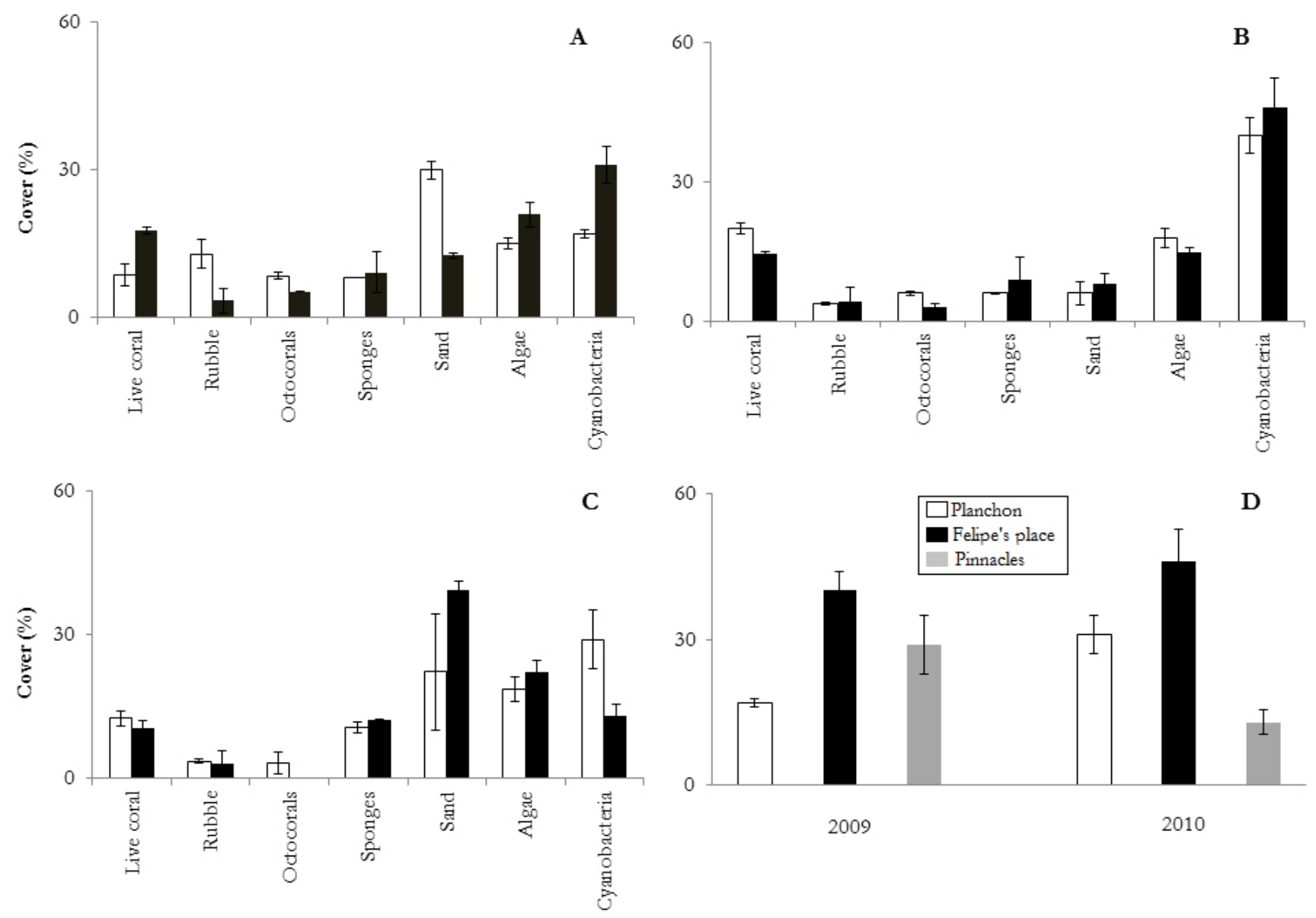

Fig. 9. Spatial and temporal comparison of the relative cover (average \pm SE) of benthic cyanobacteria and other components at three different sites: (A) Planchón, (B) Felipe's Place, and (C) Pinnacles in Old Providence Island during the wet season, (D) cyanobacteria coverage in October-November 2009 (white bars) and July 2010 (black bars). White bars: Planchón; Black bars: Felipe's Place; Gray bars: Pinnacles.

complanata* $8=$ Lp: Sand, algae and dead coral ${ }^{*}$ ) live coral cover never exceeded $4 \%$. Extensive cyanobacteria cover was observed associated to sandy bottoms, rubble, dead coral, seagrasses (Thalassia-Syringodium), macroalgae and mixed corals (Figure 8; Table 1).

We have witnessed high benthic cyanobacterial cover off Old Providence Island over the years. In 2009 and 2010, cyanobacteria cover was greater than $15 \%$, of the total benthic cover in most cases (Figure 9), surpassing live coral cover. Cyanobacteria coverage increased from 2009 to 2010, except for the Pinnacles area.
As a general trend, blooms of benthic cyanobacteria developed during the wet season and warmer months of the year from July to late October, while drifting cyanobacteria developed on October-November after periods of heavy rains. In both scenarios, blooms also developed during episodes of calm water conditions due to decreased wind speed and low current action.

\section{Discussion}

Blooms of marine benthic cyanobacteria have been recorded in the Caribbean region (Hayes et al. 2001, 
Paerl 2002, Ritson-Williams et al. 2005, Littler et al. 2006). These are now common in Puerto Rico (Stielow \& Ballantine 2003), the Bahamas, Belize and St. John in the US Virgin Islands (Paul et al. 2005, Ritson-Williams et al. 2005), as well as in Mexico (Escobar \& Machain 2005), Costa Rica (Muñoz-Simon 2012), and Florida (Paul et al. 2005). In the southern Caribbean, Prato (2013) noted bloom of benthic cyanobacteria in the continental and oceanic islands of Colombia. To date, however, there are no reports of marine cyanobacterial blooms in the Colombian Caribbean (particularly planktonic blooms), although several species have been recorded in floristic lists in the region (DíazPulido \& Díaz-Ruíz 2003, Reyes et al. 2013). Benthic cyanobacterial mats in Old Providence, consisted of complex consortia belonging to the genera Okeania, Lyngbya, Symploca, Phormidium and Oscillatoria which have also been reported in other tropical areas (Hamisi et al. 2004, Thacker \& Paul 2004, Charpy et al. 2010, Engene et al. 2013a, b). At Old Providence Island, as well as in other Colombian Caribbean reefs off the continental shelf such as Rosario Islands and Barú, cyanobacteria have become more conspicuous, frequently surpassing live coral cover (Puyana M \& Acosta A, unpub. data). However, the impacts of benthic cyanobacteria in the Colombian Caribbean were only recently addressed in studies aimed at understanding their distribution and ecological interactions (Prato 2013) as well as their natural product's chemistry (Bayona 2011, Quintana 2011). Nonetheless, the apparent cyclic nature of cyanobacterial bloom onset over diminished coral cover has not been assessed.

We observed that cyanobacteria affected four marine ecosystems (soft bottom, seagrasses, coral reefs and the pelagic zone), most geomorphological reef zones and several marine habitats. Paul et al. (2005) and Engene et al. (2013b) have also found that benthic cyanobacteria grow and develop over various kinds of substrates.

Oceanic and continental Colombian reefs were once dominated by corals. Nowadays, however, other benthic components such as cyanobacteria or macroalgae, are much more conspicuous. We do not know if high cyanobacterial coverage represents a real tendency, or only reflects the fact that we are currently acknowledging their presence. We also ignore whether they are a permanent or temporal component of the benthos. This demands thorough monitoring efforts. Of the twenty five habitats recognized in the Old Providence reef complex, 30\% of them had cyanobacteria coverage $>18 \%$. Hence cyanobacteria have become important and obvious benthic components, surpassing in many cases, live coral. Such was the case of habitat 1 (FRBRL: Cyanobacteria and sand), habitat 2 (FR: Cyanobacteria, algae-dead coral and mixed coral-octocoral-sand), habitat 3 (L: Seagrass, cyanobacteria and sand) habitat 4 (L: Sand, cyanobacteria and octocorals) and habitat 5 (FRBRL: Sand and cyanobacteria). These results indicate that cyanobacteria can reach significant coverage in habitats dominated by live organisms such as corals, macroalgae, seagrasses or octocorals.

Of particular interest are the potential effects of these blooms on habitats with live coral cover, because cyanobacteria may be aggressive space competitors, diminishing the availability of adequate substrates for larval settlement and affecting the recruitment of juvenile corals (Paerl 2002, McCook et al. 2001, Kuffner et al. 2006, Prato 2013). Cyanobacteria also developed on macroalgae. According to our observations, macroalgae seem to provide substrate for cyanobacteria since filaments get entangled in the algae, thus preventing detachment by water motion. As algae become more abundant in coral reefs, they may potentially harbor more cyanobacteria. We have not addressed any effects (negative or positive) of cyanobacteria growing over algae, but we cannot discard the notion that they might compete for the same resources, such as substrate, light and/or nutrients (Paul et al. 2005, Paul et al. 2011). In Old Providence island, seagrasses were not exempt of cyanobacteria growth. Seagrasses act as sediment and nutrient traps, providing substrate and resources for cyanobacterial growth (Stielow \& Ballantine 2003, Hamisi et al. 2004, Albert et al. 2005). We have witnessed how profuse growth of benthic cyanobacteria, eliminated, in a few month period, a patch of Thalassia and Syringodium in San Andres Island, after continuous exposure of wastewater discharged by a hotel directly into the sea (Acosta A, unpubl. data). According to Miller (2009) the dominance of cyanobacteria and fleshy macroalgae on seagrass beds in St. Barthelemy Island is an indicator of elevated land-based sources of nutrient pollution such as run-off from coastal development, septic tank leakage and sewage input. 
In our surveys, cyanobacteria were more widespread and frequent over shallow $(1-15 \mathrm{~m})$ sandy substrates and over dead corals. Greater light availability and low rugosity could favor the development of microbial mats over sandy bottoms. These hypotheses however, require further testing. Another advantage of growing on sandy bottoms and dead corals could be related to the lack of competitive interactions with other benthic organisms such as cnidarians that may pose some kind of resistance to cyanobacterial growth at various levels (Kuffner et al. 2006). Low perturbation by grazers in sandy bottoms, and a low herbivory regime over dead coral, may also facilitate the formation of cyanobacterial mats on benthic habitats (Fenchel 1998).

Sites with the greatest density of cyanobacteria, as well as habitats with the highest cyanobacteria coverage, were located at the NW portion of the island. This area is subject to several anthropic influences and pollution sources such as the Santa Isabel pier, the sanitary landfill, two of the main towns of the island (Old Town and Free Town, which have more than 100 inhabitants $/ \mathrm{km}^{2}$ ), and fresh water discharge from agricultural and livestock activities through temporary and permanent gullies (Figures 5 and 6; Vides \& Sierra-Correa 2003, CORALINAINVEMAR 2012). In addition, at the NW portion of the coral reef complex, there is a convergence of local currents in the island (Prahl 1983; Figure 1), which may help concentrate the cyanobacteria as well as the resources they require to grow.

A high cyanobacteria percent coverage was found at the NW of Providence over several habitats (18 -72 $\%$ ). Similar values have been reported in other tropical areas. Stielow and Ballantine (2003) monitored blooms of Lyngbya majuscula off the coasts of Puerto Rico from September 1998 until February 2000. Total coverage of cyanobacteria ranged between $7 \%$ and $82 \%$, occasionally reaching a 100\% cover. Likewise, Ahern et al. (2007b) mapped and described the temporal dynamics of a Lyngbya majuscula bloom in Australia. The bloom was seasonal, ranging from a cover of less than $10 \%$ (49 hectares) up to $40 \%$ (329 hectares). Once the bloom reached its highest peak, it covered almost $100 \%$ (529 hectares) of the bottom. Although the total coverage of benthic cyanobacteria in Old Providence Island never reached $100 \%$ in any habitat or ecosystem, the observed patterns in coverage of benthic cyanobacteria correspond well to those values reported in the literature for degraded reefs.

In our study, the habitats surveyed with cyanobacteria -as a major component- covered an area equivalent to $19.2 \mathrm{~km}^{2}$. Roughly $23 \%$ of this area $\left(4.4 \mathrm{~km}^{2}\right)$ had a cyanobacteria cover $>18 \%$. Of the total area covered by cyanobacteria, $96 \%\left(4.3 \mathrm{~km}^{2}\right)$ had a coverage $>18 \%$. We propose that cyanobacteria coverage $>15 \%$ could be used as a threshold level to indicate adverse reef health in Old Providence Island.

In Old Providence Island a massive bloom of planktonic cyanobacteria was also registered at the NW portion of the island. This bloom increased turbidity and restricted light penetration in the water column (Suppl. 1). Planktonic cyanobacterial blooms affect water quality, planktonic and benthic communities (Kuffner et al. 2006, Paerl \& Paul 2012). Drifting cyanobacteria eventually sink, producing a thick cyanobacterial mat covering the reef for some weeks. Some of the competitive mechanisms between cyanobacteria against corals, octocorals or algae include anoxia, overgrowth or allelopathic effects via the production and exudation of toxins or allelochemical compounds (Hawser et al. 1992, Paerl 2002, Kuffner \& Paul 2004, Codd et al. 2005, Ritson-Williams et al. 2005, Kuffner et al. 2006, Littler et al. 2006, Titlyanov et al. 2007), which cause polyp retraction, bleaching, tissue loss or mortality (Ritson-Williams et al. 2005, Littler et al. 2006, Smith et al. 2008, Hauri et al. 2010). Additionally, several authors have indicated that cyanobacteria and turf algae may prevent or inhibit the settlement of coral larvae (Edmunds \& Carpenter 2001, McCook et al. 2001, Kuffner \& Paul 2004, Kuffner et al. 2006, Vermeij et al. 2010), or favor the transport or settlement of potential pathogens that induce coral diseases. Recent studies in Old Providence Island (Acosta et al. 2011, Bernal-Sotelo \& Acosta 2012) show that less than $10 \%$ of live coral cover remains, whereas two decades earlier live coral occupied up to 35-40 \% of the reef hard substrates (Acosta \& Martínez 2006). Low live coral cover and relatively low recruitment rates (Acosta et al. 2011) could be further reduced by the onset and development of cyanobacterial blooms which can occupy the substrate for several weeks or months, forming patches of dwindling size (M. Puyana, pers. obser.), limiting the natural recovery of the reef ecosystem. These are some of the reasons why we 
consider cyanobacterial blooms as a new stressor for reef communities. Sellner (1997), Howarth et al (2000) and Gilby et al (2011) indicate that cyanobacterial blooms exert negative changes in the composition, structure and interactions in benthic (medium to long-term) and planktonic communities, altering food webs as well. It is also important to mention that several benthic cyanobacteria produce toxins that can cause liver damage, gastrointestinal or skin disorders in humans exposed to them (Golubic et al. 2010, El-Shehawy et al. 2012). To date, however, there are no reports of toxicity to humans in the Colombian Caribbean as a result of contact with marine benthic cyanobacteria.

Cyanobacterial blooms could be temporal or permanent stressors for the reef complex of Old Providence Island, depending on several factors such as the local hydrographic regime (major current heading SW), that may play an important role in the attenuation, export or temporary elimination of cyanobacteria. Becerro (2006) indicated that wave surge, storms and intense tidal flow or currents, may export large amounts of cyanobacterial biomass either to the open sea or towards other neighboring ecosystems including the seashore. We witnessed a significant accumulation of cyanobacteria at Southwest Bay (Figure 4), after a three-day period of storms. This process may eventually release the pressure in the affected ecosystems by reducing direct interactions and competition between cyanobacteria and corals, macroalgae and seagrasses.

In Old Providence Island, Prato (2013) observed high cover of benthic cyanobacteria, especially during some of the warmer months of the year (June to August), where the mean water temperature was $>29{ }^{\circ} \mathrm{C}$. We observed a similar pattern in July but extended to October-November where cyanobacteria coverage was also high. Vivas-Aguas et al. (2012) indicated May to late September as the warmer months of the year (between $28.2^{\circ} \mathrm{C} \pm 1.26 \mathrm{SD}$, with a maximum temperature of $32{ }^{\circ} \mathrm{C}$ ). Although the temperature slightly decreases in October-November, it remains high until January. This usually high temperatures at the end of the year could favor the continuity of cyanobacteria blooms. Different studies have shown that there is a positive correlation between temperature increase and cyanobacterial growth (Thacker \& Paul
2001, Watkinson et al. 2005, Ahern et al. 2007b, Paerl \& Huisman 2008). The effect of temperature on increased cyanobacteria cover was documented by Ahern et al. (2007a). The authors mapped the distribution of Lyngbya majuscula off the eastern coast of Australia in 2005 and quantified bloom coverage over time. While the authors did not find L. majuscula during the winter and early spring months, as water temperature increased (from $23{ }^{\circ} \mathrm{C}$ to $30^{\circ} \mathrm{C}$ ), Lyngbya coverage rapidly increased, reaching $40 \%$ of the substrate equivalent to an area of 329 hectares. When water temperature surpassed $32{ }^{\circ} \mathrm{C}$, the bloom had occupied an area of 529 hectares. Then, cyanobacteria coverage diminished as the water cooled down in the fall.

The bloom of planktonic cyanobacteria in Old Providence Island, on the other hand, developed following peaks of heavy rains (October-November, after periods of drought). González \& Hurtado (2012) mentioned average precipitation values for Old Providence Island of $301 \mathrm{~mm}$ in October and $266 \mathrm{~mm}$ in November, corresponding to $34 \%$ of the total annual rainfall for the island. The bloom was also observed under low wind speed conditions (flat seas, no surge) which in turn may increase the time of residence of warm water masses, particularly in the lagoon (E of the island) and shallow terraces (N, NW). González \& Hurtado (2012) stated that October $(10.1 \mathrm{~km} / \mathrm{h})$ is after September $(9.1 \mathrm{~km} / \mathrm{h})$, the month with lowest wind speed. December and January are the windiest months of the year $(15.6,15.1 \mathrm{~km} / \mathrm{h}$, respectively).

Reports of marine cyanobacterial blooms are on the rise (Paerl \& Paul 2012) and probably will be more prevalent and intense with climate change. Several chemical, physical and biological, natural or anthropogenic factors are linked to the onset and development of cyanobacterial blooms, their interaction, however, is complex (O'Neil et al. 2012). For example, the expansion of urban centers on coastal areas and the consequent contribution of wastewater increase nutrient input, affect the predominant N/P relation, reduce salinity and increase water temperature (Dennison et al. 1999, Osborne et al. 2001, Watkinson et al. 2005).

An increase in water temperatures (above $28{ }^{\circ} \mathrm{C}$ ), alterations of flow and time of residence, decrease in water viscosity, large scale mixing processes or small 
scale turbulence are physical factors that correlate with bloom formation (Paerl 2002, Watkinson et al. 2005, Ahern et al. 2007a, Paerl \& Huisman 2008, Paerl et al. 2011). Moreover, blooms of marine benthic cyanobacteria have been linked to an increase in nitrate, phosphate, ammonia or iron concentrations (Sellner 1997, O'Neil 2012, Zhang et al. 2012), and low salinity (Conley et al. 2009). Most of those stressors co-occurred in Old Providence Island, and may help to explain the underlying physical and chemical mechanisms behind cyanobacterial blooms. Historical records generated by the monitoring network of the quality of marine and coastal waters of ColombiaREDCAM (INVEMAR-REDCAM 2013), reported in Old Providence Island, from 2001 to 2012, increased concentrations of dissolved inorganic nitrogen (DIN) and orthophosphate with values of $74.4 \pm 39.43 \mu \mathrm{g} / \mathrm{L}$ (281 $\mu \mathrm{g} / \mathrm{L}$ max.) and 88.9 $\pm 183.7 \mu \mathrm{g} / \mathrm{L}$, respectively (1352 $\mu \mathrm{g} / \mathrm{L}$ max.). Similar values were also reported by Vivas-Aguas et al. 2012). However, greater nutrient levels are invariably registered during the wet season (Vivas-Aguas et al. 2012). Nutrient peaks at the stations Santa Isabel, San Felipe and McBean, have been associated to the vicinity of human settlements and tourism (especially in the Santa Isabel wharf), leachates from the landfill at sector of San Felipe and the input of organic and inorganic residues from agricultural activity, animal husbandry and mangrove areas in the watershed of McBean Lagoon (Figure 5, 6; Vivas-Aguas et al. 2012). The current levels of DIN and phosphates surpass, in an order of magnitude, those considered standard for oligotrophic reef waters $14 \mu \mathrm{g} / 1(=1 \mu \mathrm{M})$ for DIN and $3.1 \mu \mathrm{g} / \mathrm{l}$ $(=0.1 \mu \mathrm{M})$ for soluble phosphorus (Fabricius 2005). Greater nutrient levels promote algal development, which may help to explain the observed blooms. Further nutrient increase affects coral growth, reproduction and recruitment (Fabricius 2005).

The literature indicates that cyanobacterial blooms have consequences at various ecological scales (landscape, ecosystem, community, population and individual). Considering the extension and the apparent pulsing nature of cyanobacterial blooms in Old Providence Island, part of a UNESCO's Biosphere Reserve, it is important to mitigate the potential causative agents of these events. There is a strong need to further study the frequency, scale and duration of these events, and to understand the consequences of blooms related to the biodiversity and the environmental services the affected areas provide. For these reasons, there is a strong need to establish a long term monitoring program in the region in order to understand and follow this new stressor. From a practical standpoint, we propose that the cover ratio between live coral and cyanobacteria could be used as an indicator of reef degradation. A threshold value of benthic cyanobacteria cover greater than $15 \%$ could be indicative of degradation in coral reef ecosystems.

\section{Conclusion}

In conclusion, in Old Providence Island, blooms of benthic and planktonic cyanobacteria developed in four ecosystems (sandy bottoms, seagrasses, coral reefs and the pelagic zone), six geomorphological zones (Backreef terrace, Patch reefs, Pinnacles, Fringing reefs, Fore-reef terrace and Lagoon) and nine habitats. The prevalence of cyanobacteria around Old Providence was very high. During cyanobacterial blooms, five of the nine habitats had high cyanobacteria cover (from 18 to $72 \%$ ). Blooms covered over $4.2 \mathrm{~km}^{2}$ of the reef complex, particularly in those habitats with low live coral and high coverage of sand, macroalgae, dead coral or seagrasses. Cyanobacterial blooms are considered a new stressor in reef communities in the island and have an apparent pulsing nature. Therefore, it is important to understand the local conditions favoring these events in order to mitigate potential causal agents. We propose that benthic cyanobacteria cover greater than $15 \%$ can be used as an indicator of degradation in coral reef ecosystems.

\section{Acknowledgments}

We want to thank Vicerrectoría Académica from Pontificia Universidad Javeriana (ID Propuesta 4535; ID Proyecto 4318), Colciencias (Project 1216-452-21241), Universidad Jorge Tadeo Lozano, Fundación para la Promoción de la Investigación y la Tecnología del Banco de la República, Fundación Mariano Ospina Pérez-ICETEX and Universidad de Costa Rica, for financial support. We want to acknowledge the GeoEye Foundation-Imagery Grants for donation of the satellite imagery. Research permits were granted by MAVDT (Permit No. 4 of 10/02/2010) and CORALINA (Permit 00112). Three anonymous reviewers provided helpful comments on earlier drafts of the manuscript. We are very grateful to JA Prato, U Steele, D Steele, J Vásquez, P Gamboa, Scuba Town and Sirius Dive shops for their assistance during field surveys. Cyndy A. Pachón and JA Prato performed 
taxonomic analyses of cyanobacterial mats. A Fonseca and C Benavides from Universidad de Costa Rica provided useful insights on cartographic analyses. CORALINA contributed information on environmental parameters. Cartographic information was supplied by INVEMAR. Thanks to Dr. J Cortés from Universidad de Costa Rica for his invaluable contributions on coral reef ecology and to Dr. Valerie Paul Director of the Smithsonian Marine Station at Fort Pierce, for her guidance and generous advice on the intricate aspects of the taxonomy and chemistry of marine cyanobacteria. This paper is dedicated to the Raizal community of Old Providence Island.

\section{Conflict of Interest}

Alberto Acosta, as editor of Universitas Scientarum, declares a conflict of interest. Therefore, the entire review process and approval of the manuscript was handled and edited by Luz Teresa Valderrama (co-editor of Universitas Scientarum).

\section{References}

Acosta A, Acevedo A (2006) Population structure and colony condition of Dendrogyra cylindrus (Anthozoa: Scleractinia) in Old Providence Island, Colombian Caribbean Proceedings of the 10th International Coral Reef Symposium, Japan, pp 1605-1610

Acosta A, Dueñas LF, Pizarro V (2011) Review on hard coral recruitment (Cnidaria: Scleractinia) in Colombia. Universitas Scientiarum 16(3):200-218

Acosta A, Martínez S (2006) Continental and oceanic coral reefs in the Colombian Caribbean after a decade of degradation Proceedings of the 10th International Coral Reef Symposium, Japan, pp 1926-1930

Ahern K, Ahern C,UdyJ (2007a) Nutrientadditions generate prolific growth of Lyngbya majuscula (cyanobacteria) in field and bioassay experiments. Harmful Algae 6(1):134151 doi 10.1016/J.Hal.2006.08.004

Ahern KS, Ahern CR, Savige GM, Udy JW (2007b) Mapping the distribution, biomass and tissue nutrient levels of a marine benthic cyanobacteria bloom (Lyngbya majuscula). Marine and Freshwater Research 58(10):883-904 doi 10.1071/Mf07065

Ahern K, Ahern C, Udy J (2008) In situ field experiment shows Lyngbya majuscula (cyanobacterium) growth stimulated by added iron, phosphorus and nitrogen. Harmful Algae 7(4):389-404 doi 10.1016/J. Hal.2007.08.006

Albert S, O'Neil J, Udy J, Ahern K, O'Sullivan C, Dennison W (2005) Blooms of the cyanobacterium Lyngbya majuscula in coastal Queensland, Australia: Disparate sites, common factors. Marine Pollution Bulletin 51(14):428-437 doi 10.1016/j.marpolbul.2004.10.016
Aronson R, Precht W (2006) Conservation, precaution, and Caribbean reefs. Coral Reefs 25(3):441-450 doi 10.1007/ S00338-006-0122-9

Arthur K, Limpus C, Balazs G, Capper A, Udy J, Shaw G, Keuper-Bennett U, Bennett P (2008) The exposure of green turtles (Chelonia mydas) to tumour promoting compounds produced by the cyanobacterium Lyngbya majuscula and their potential role in the aetiology of fibropapillomatosis. Harmful Algae 7(1):114-125 doi 10.1016/J.Hal.2007.06.001

Bayona L (2011) Estudio de compuestos con actividad citotóxica aislados de cianobacterias bentónicas del Caribe Colombiano. Trabajo de grado. Programa de Química, Facultad de Ciencias. Universidad Nacional de Colombia, Bogotá, Colombia. 8 p

Becerro M, Bonito V, Paul V (2006) Effects of monsoondriven wave action on coral reefs of Guam and implications for coral recruitment. Coral Reefs 25(2):193199 doi 10.1007/S00338-005-0080-7

Benfield SL, Guzman HM, Mair JM, Young JAT (2007) Mapping the distribution of coral reefs and associated sublittoral habitats in Pacific Panama: a comparison of optical satellite sensors and classification methodologies. International Journal of Remote Sensing 28(22):5047-5070 doi 10.1080/01431160701258062

Bernal-Sotelo K, Acosta A (2012) The relationship between physical and biological habitat conditions and hermatypic coral recruits abundance within insular reefs (Colombian Caribbean). Revista de Biología Tropical 60(3):995-1014

Bolaños N, Acosta A (2013) ¿Qué perdió Colombia con el fallo de la Haya?. Revista Javeriana 792(149):56-62

Burke L, Maidens J (2004) Reefs at risk in the Caribbean. World Resources Institute Washington, DC

Butler MI (1995) Cascading disturbances in Florida Bay, USA: Cyanobacteria blooms, sponge mortality, and implications for juvenile spiny lobsters Panulirus argus. Marine Ecology Progress Series 129(1-3):119-125

Charpy L, Casareto B, Langlade M-J, Suzuki Y (2012) Cyanobacteria in coral reef ecosystems: A review. Journal of Marine Biology 2012:1-9 doi 10.1155/2012/259571

Charpy L, Palinska K, Casareto B, Langlade M, Suzuki Y, Abed R, Golubic S (2010) Dinitrogen-fixing cyanobacteria in microbial mats of two shallow coral reef ecosystems. Microbial Ecology 59(1):174-186 doi 10.1007/s00248-009-9576-y

Chorus I, Bartram J (1999) Toxic cyanobacteria in water: a guide to their public health consequences, monitoring and management. World Health Organization, London 416 p

Chuvieco E (2008) Teledetección ambiental. La observación de la tierra desde el espacio. Ariel, Barcelona, España. $594 \mathrm{p}$ 
Codd G, Lindsay J, Young F, Morrison L, Metcalf J (2005) Harmful cyanobacteria. In: Huisman J, Matthijs HP, Visser P (eds) Harmful cyanobacteria. Springer Dordrecht, pp 1-23

Conley D, Paerl H, Howarth R, Boesch D, Seitzinger S, Havens K, Lancelot C, Likens G (2009) Controlling eutrophication: nitrogen and phosphorus. Science 323(5917):1014-1015 doi 10.1126/science.1167755

CORALINA-INVEMAR. 2012. Gómez-López, D. I., C. Segura-Quintero, P. C. Sierra-Correa y J. Garay-Tinoco (Eds). Atlas de la Reserva de Biósfera Seaflower. Archipiélago de San Andrés, Old Providence y Santa Catalina. Instituto de Investigaciones Marinas y Costeras "José Benito Vives De Andréis" -INVEMARy Corporación para el Desarrollo Sostenible del Archipiélago de San Andrés, Old Providence y Santa Catalina -CORALINA-. Serie de Publicaciones Especiales de INVEMAR \# 28. Santa Marta, Colombia $180 \mathrm{p}$

Dennison W, O'Neil J, Duffy E, Oliver P, Shaw G (1999) Blooms of the cyanobacterium Lyngbya majuscula in coastal waters of Queensland, Australia. Bulletin de l'Institut Océanographique de Monaco 501-506 INISTCNRS, Cote INIST : 834, 35400008032915.0520

Díaz J (2005) Esquemas espaciales de zonación ecológica y morfología de las Lagunas de los atolones y complejos arrecifales de un archipiélago oceánico del Caribe: San Andrés y Old Providence (Colombia). La Revista de la Academia de Ciencias Exactas, Físicas y Naturales 29:357369

Díaz J, Barrios L, Cendales M, Garzón-Ferreira J, Geister J, López-Victoria M, Ospina GH, Parra-Velandia F, Pinzón J, Vargas-Angel B, Zapata FA, Zea S (2000) Áreas coralinas de Colombia. INVEMAR, Santa Marta. Colombia

Díaz J, Díaz G, Garzón-Ferreira J, Sánchez J, Zea S (1996) Atlas de los arrecifes coralinos del Caribe colombiano y complejos arrecifales oceánicos. INVEMAR, Santa Marta

Díaz-Pulido G, Díaz-Ruíz M (2003) Diversity of benthic marine algae of the Colombian Atlantic. Biota Colombiana 4(2):203-246

Edmunds PJ, Carpenter RC (2001) Recovery of Diadema antillarum reduces macroalgal cover and increases abundance of juvenile corals on a Caribbean reef. Proceedings of the National Academy of Sciences of the United States of America 98(9):5067-5071 doi 10.1073/ pnas. 071524598

El-Shehawy R, Gorokhova E, Fernández-Piñas F, del Campo F (2012) Global warming and hepatotoxin production by cyanobacteria: what can we learn from experiments? Water Research 46(5):1420-1429 doi 10.1016/j.watres.2011.11.021
Engene N, Choi H, Esquenazi E, Rottacker EC, Ellisman MH, Dorrestein PC, Gerwick WH (2011) Underestimated biodiversity as a major explanation for the perceived rich secondary metabolite capacity of the cyanobacterial genus Lyngbya. Environmental Microbiology 13(6):1601-1610 doi 10.1111/J.14622920.2011.02472.X

Engene N, Coates R, Gerwick W (2010) 16s rRNA gene heterogeneityin the filamentousmarine cyanobacterial genus Lyngbya. Journal of Phycology 46(3):591-601 doi 10.1111/J.1529-8817.2010.00840.X

Engene N, Gunasekera S, Gerwick W, Paul V (2013a) Phylogenetic inferences reveal a large extent of novel biodiversity in chemically rich tropical marine cyanobacteria. Applied and environmental microbiology 79(6):1882-1888 doi 10.1128/AEM.03793-12

Engene N, Paul VJ, Byrum T, Gerwick WH, Thor A, Ellisman MH (2013b) Five chemically rich species of tropical marine cyanobacteria of the genus Okeania gen. nov. (Oscillatoriales, Cyanoprokaryota). Journal of Phycology 49(6):1095-1106 doi 10.1111/jpy.12115

Engene N, Rottacker E, Kastovsky J, Byrum T, Choi H, Ellisman M, Komarek J, Gerwick W (2012) Moorea producens gen. nov., sp. nov. and Moorea bouillonii comb. nov., tropical marine cyanobacteria rich in bioactive secondary metabolites. International Journal of Systematic and Evolutionary Microbiology 62:11711178 doi 10.1099/ijs.0.033761-0

Escobar E, Machain ML (2005) México. In: Miloslavich P, Klein E (eds) Caribbean marine biodiversity: the known and the unknown. DEStech Publications, Inc., USA, pp 334

Fabricius K (2005) Effects of terrestrial runoff on the ecology of corals and coral reefs: review and synthesis. Marine Pollution Bulletin 50: 125-146 doi 10.1016/j.marpolbul.2004.11.028

Fenchel T (1998) Formation of laminated cyanobacterial mats in the absence of benthic fauna. Aquatic Microbial Ecology, 14: 235-240

Frias-Lopez J, Bonheyo G, Jin Q, Fouke B (2003) Cyanobacteria associated with coral black band disease in Caribbean and Indo-Pacific reefs. Applied and Environmental Microbiology 69(4):2409-2413 doi 10.1128/AEM.69.4.2409-2413.2003

García M, McCormick C, Chow R, Peñaloza G, Connollly E, Mitchell A, Hudson G, Howard M (2003) Plan de manejo integrado de las áreas marinas protegidas parte I. Corporación para el Desarrollo Sostenible del Archipiélago de San Andrés, Old Providence y Santa Catalina, San Andrés. CORALINA, San Andrés 
Gavio B, Palmer-Cantillo S, Mancera JE (2010) Historical analysis (2000-2005) of the coastal water quality in San Andrés Island, SeaFlower Biosphere Reserve, Caribbean Colombia. Marine Pollution Bulletin 60(7):1018-1030 doi 10.1016/j. marpolbul.2010.01.025

Geister J (1977) The influence of wave exposure on the ecological zonation of Caribbean coral reefs Proceedings of the 3rd International Coral Reef Symposum, USA, pp 23-29

Geister J (1986) Recent coral reefs and geologic history of Old Providence island (western Caribbean sea, Colombia). Geología Colombiana 15:115-134

Geister J, Diaz J (1997) A field guide to the oceanic barrier reefs and atolls of the southwestern Caribbean (Archipelago of San Andrés and Old Providence, Colombia), Proceedings of the 8th International Coral Reef Symposium, Panamá, pp 235-263

Gilby BL, Burfeind DD, Tibbetts IR (2011) Lyngbya majuscula blooms and the diet of small subtropical benthivorous fishes. Marine Biology 158: 245-255.

Golubic S, Abed RMM, Palińska K, Pauillac S, Chinain M, Laurent D (2010) Marine toxic cyanobacteria: diversity, environmental responses and hazards. Toxicon 56(5):836-841 doi 10.1016/j.toxicon.2009.07.023

González O, Hurtado G (2012) Caracterización climática del archipiélago de San Andrés y Providencia. 47-52 p. In: CORALINA-INVEMAR. Gómez-López D, SeguraQuintero C, Sierra-Correa P, Garay-Tinoco J (eds) Atlas de la reserva de la Biósfera Seaflower, Archipiélago de San Andrés, Old Providence y Santa Catalina. Instituto de Investigaciones Marinas y Costeras "José Benito Vives de Andréis" -INVEMAR-, Corporación para el Desarrollo Sostenible del Archiépelago de San Andrés, Old Providence y Santa Catalina -CORALINA-, Santa Marta, Colombia, pp 180

Hallegraeff GM (1993) A review of harmful algal blooms and their apparent global increase. Phycologia 32: 79-99

Hallock P (2005) Global change and modern coral reefs: New opportunities to understand shallow-water carbonate depositional processes. Sedimentary Geology 175(1-4):19-33 doi 10.1016/J.Sedgeo.2004.12.027

Hamisi M, Lyimo TJ, Muruke MHS (2004) Cyanobacterial occurrence and diversity in seagrass meadows in coastal Tanzania. Western Indian Ocean Journal of Marine Science, 3(2): 113-122

Hauri C, Fabricius KE, Schaffelke B, Humphrey C (2010) Chemical and physical environmental conditions underneath mat- and canopy-forming macroalgae, and their effects on understorey corals. PLOS ONE 5(9):e12685 doi 10.1371/journal.pone.0012685
Havens K (2008) Cyanobacteria blooms: effects on aquatic ecosystems. In: Hudnell H (ed) Cyanobacterial harmful algal blooms: State of the science and research needs. Springer New York, pp 733-747

Hawser S, O'Neil J, Roman M, Codd G (1992) Toxicity of blooms of the cyanobacterium Trichodesmium to zooplankton. Journal of Applied Phycology 4(1):79-86 doi 10.1007/BF00003963

Hayes M, Bonaventura J, Mitchell T, Prospero J, Shinn E, Dolah F, Barber R (2001) How are climate and marine biological outbreaks functionally linked? In: Porter J (ed) The ecology and etiology of newly emerging marine diseases. Kluwer Academic Publishers, Dordrecht, pp 213-220

Hedley JD, Harborne AR, Mumby PJ (2005) Technical note: simple and robust removal of sun glint for mapping shallow-water benthos. International Journal of Remote Sensing 26(10):2107-2112 doi 10.1080/01431160500034086

Howarth R, Anderson D, Cloern J, Elfring C, Hopkinson C, Lapointe B, Malone T, Marcus N, McGlathery K, Sharpley A, Walker D (2000). Nutrient pollution of coastal rivers, Bays, and Seas. Issues in Ecology, 7: 1-15

Hughes TP, Graham NAJ, Jackson JBC, Mumby PJ, Steneck RS (2010) Rising to the challenge of sustaining coral reef resilience. Trends in Ecology \& Evolution 25(11):633642 doi http://dx.doi.org/10.1016/j.tree.2010.07.011

Huisman J, Hulot F (2005) Population dynamics of harmful cyanobacteria. In: Huisman J, Matthijs HP, Visser P (eds) Harmful cyanobacteria. Springer Dordrecht, pp 143-176

Humpage A (2008) Toxin types, toxicokinetics and toxicodynamics. In: Hudnell $\mathrm{H}$ (ed) Cyanobacterial harmful algal blooms: State of the science and research needs. Springer New York, pp 383-415

INVEMAR-REDCAM (2013) Red de Vigilancia de la Calidad Ambiental Marina en Colombia - REDCAM. [Santa Marta]: Instituto de investigaciones Marinas y Costeras "José Benito Vives de Andréis", [Mayo 2013]. <http://siam.invemar.org.co/siam/redcam> [Consulta: 31/5/2013 6:23 PM].

Komárek J, Anagnostidis K (2005) Cyanoprokaryota: 2. Teil/Part 2. Oscillatoriales. Spektrum Akademischer Verlag, Heidelberg

Kuffner I, Paul V (2004) Effects of the benthic cyanobacterium Lyngbya majuscula on larval recruitment of the reef corals Acropora surculosa and Pocillopora damicornis. Coral Reefs 23(3):455-458 doi 10.1007/S00338-004-0416-8

Kuffner I, Walters L, Becerro M, Paul V, Ritson-Williams R, Beach K (2006) Inhibition of coral recruitment by macroalgae and cyanobacteria. Marine Ecology Progress Series 323:107-117 doi 10.3354/Meps323107 
Leão P, Engene N, Antunes A, Gerwick W, Vasconcelos V (2012) The chemical ecology of cyanobacteria. Natural Product Reports 29(3):372-391 doi 10.1039/c2np00075j

Littler M, Littler D, Lapointe B, Barile P (2006) Toxic cyanobacteria (blue-green algae) associated with groundwater conduits in the Bahamas. Coral Reefs 25(2):186-186 doi 10.1007/S00338-005-0010-8

Lyzenga DR (1981) Remote sensing of bottom reflectance and water attenuation parameters in shallow water using aircraft and Landsat data. International Journal of Remote Sensing 2(1):71-82 doi 10.1080/01431168108948342

Madden CJ, Goodin K, Allee R, Bamford D, Finkbeiner M (2008) Clasificación ecológica estandarizada costera y marina. NatureServe y NOAA, Arlington

McCook L, Jompa J, Diaz-Pulido G (2001) Competition between corals and algae on coral reefs: a review of evidence and mechanisms. Coral Reefs 19(4):400-417 doi $10.1007 / \mathrm{s} 003380000129$

Metcalf J, Codd G (2004) Cyanobacterial toxins in the water environment: a review of current knowledge. Foundation for Water Research, Marlow

Miller C, Brosnan D, Clarke R, Oltman-Shay J, Stair C (2009) Evaluation of current status of seagrasses and marine ecosystem health in St. Jean Bay, St. Barthelemy FWI. Sustainable Ecosystems Institute, St Jean Bay Science Group. 27 pp

Miller MA, Kudela RM, Mekebri A, Crane D, Oates SC, Tinker MT, Staedler M, Miller WA, Toy-Choutka S, Dominik C, Hardin D, Langlois G, Murray M, Ward K, Jessup DA (2010) Evidence for a novel marine harmful algal bloom: cyanotoxin (microcystin) transfer from land to sea otters. PLoS ONE 5(9):1-11 doi 10.1371/ journal.pone.0012576

Mora C (2008) A clear human footprint in the coral reefs of the Caribbean. Proceedings of the Royal Society of London B 275(1636):767-773 doi 10.1098/rspb.2007.1472

Mumby P, Edwards A (2000) Water column correction techniques. Remote sensing handbook for tropical coastal management. Coastal Management Sourcebook, pp 121-128

Mumby PJ, Steneck RS (2008) Coral reef management and conservation in light of rapidly evolving ecological paradigms. Trends in Ecology and Evolution 23(10):555-563 doi 10.1016/j.tree.2008.06.011

Muñoz-Simon N (2012) Cianobacterias bentónicas marinas en el Caribe central y sur de Costa Rica. Revista Ciencias Marinas y Costeras; Vol 4 (2012)

Nagle D, Paul V (1998) Chemical defense of a marine cyanobacterial bloom. Journal of Experimental Marine Biology and Ecology 225(1):29-38 doi 10.1016/S00220981(97)00205-0
Nagle D, Paul V (1999) Production of secondary metabolites by filamentous tropical marine cyanobacteria: ecological functions of the compounds. Journal of Phycology 35:1412-1421 doi 10.1046/j.1529-8817.1999.3561412.x

O'Neil J, Shaw G, Dennison W (2000) Blooms of the toxic cyanobacteria Lyngbya majuscula in coastal Queesland Waters 9th International Conference on Harmful Blooms, Hobart, pp 7-11

O’Neil J, Davis T, Burford M, Gobler C (2012) The rise of harmful cyanobacteria blooms: the potential roles of eutrophication and climate change. Harmful Algae 14(0):313-334 doi 10.1016/j.hal.2011.10.027

Osborne NJT, Webb PM, Shaw GR (2001) The toxins of Lyngbya majuscula and their human and ecological health effects. Environment International, 27: 381-392

Paerl H (2002) Marine plankton. In: Whitton B, Potts M (eds) The ecology of cyanobacteria. Kluwer Academic Publishers, New York, pp 121-148

Paerl H, Huisman J (2008) Blooms like it hot. Science 320(5872):57-58 doi 10.1126/science. 1155398

Paerl H, Hall N, Calandrino E (2011) Controlling harmful cyanobacterial blooms in a world experiencing anthropogenic and climatic-induced change. Science of the Total Environment 409(10):1739-1745 doi 10.1016/j. scitotenv.2011.02.001

Paerl H, Paul V (2012) Climate change: Links to global expansion of harmful cyanobacteria. Water Research 46(5):1349-1363 doi 10.1016/j.watres.2011.08.002

Paerl HW, Huisman J (2009) Climate change: A catalyst for global expansion of harmful cyanobacterial blooms. Environmental Microbiology Reports 1(1):27-37 doi 10.1111/j.1758-2229.2008.00004.x

Paul V (2008) Global warming and cyanobacterial harmful algal blooms. In: Hudnell H (ed) Cyanobacterial harmful algal blooms: State of the science and research needs. Springer, New York, pp 239-257

Paul V, Cruz-RiveraE, Thacker R (2001)Chemical mediation of macroalgal-herbivore interactions: Ecological and evolutionary perspectives. In: McClintock J, Baker B (eds) Marine Chemical Ecology. CRC Press, Boca Ratón, Florida, EEUU, pp 227-265

Paul V, Thacker R, Banks K, Golubic S (2005) Benthic cyanobacterial bloom impacts the reefs of South Florida (Broward County, USA). Coral Reefs 24(4):693697 doi 10.1007/s00338-005-0061-x

Paul VJ, Ritson-Williams R, Sharp K (2011) Marine chemical ecology in benthic environments. Natural Product Reports 28(2):345-387 doi 10.1039/C0NP00040J

Pennings S, Pablo S, Paul V (1997) Chemical defenses of the tropical, benthic marine cyanobacterium Hormothamnion enteromorphoides: Diverse consumers and synergisms. Limnology and Oceanography 42 (5 I):911-917 
Pittman SJ, Pittman KM (2005) Short-term consequences of a benthic cyanobacterial bloom (Lyngbya majuscula Gomont) for fish and penaeid prawns in Moreton Bay (Queensland, Australia). Estuarine, Coastal and Shelf Science 63(4):619-632 doi 10.1016/j.ecss.2005.01.007

Prahl HV (1983) Notas sobre las formaciones de manglares y arrecifes coralinos en la Isla de Old Providence, Colombia. En: Memorias Seminario 'Desarrollo y Planificación Ambiental en las Islas de San Andrés y Old Providence'. FIPMA \& Ministerio de Agricultura, Bogotá. 57-67

Prato J (2013) Afloramientos de cianobacterias marinas bentónicas en San Andrés, Old Providence y las Islas del Rosario (Caribe Colombiano): caracterización y evaluación de su posible papel ecológico. Tesis de Maestría, Postgrado Interfacultades-Microbiología, Universidad Nacional de Colombia. Bogotá, Colombia. 184 p

Quintana J (2011) Evaluación de la toxicidad y del potencial bioactivo de afloramientos de cianobacterias bentónicas arrecifales del Caribe Colombiano. Tesis de Maestría en Ciencias-Química, Facultad de Ciencias, Universidad Nacional de Colombia. Bogotá, Colombia. 112 p

Rasher D, Hay M (2010) Chemically rich seaweeds poison corals when not controlled by herbivores. Proceedings of the National Academy of Sciences of the United States of America 107(21):9683-9688 doi 10.1073/pnas.0912095107

Realpe A, Díaz-Granados J, Acevedo M (2012) Electricity generation and wind potential assessment in regions of Colombia. DYNA 79:116-122

Reyes V, Gavio B, Velásquez H (2013) Notes on the marine algae of the International Biosphere Reserve Seaflower, III. New records of Cyanophyta for the Caribbean coast of Colombia. Nova Hedwigia 97:349-360

Ritson-Williams R, Paul V, Bonito V (2005) Marine benthic cyanobacteria overgrow coral reef organisms. Coral Reefs 24(4):629 doi 10.1007/s00338-005-0059-4

River G, Edmunds P (2001) Mechanisms of interaction between macroalgae and scleractinians on a coral reef in Jamaica. Journal of Experimental Marine Biology and Ecology 261(2):159-172 doi 10.1016/S0022-0981(01)00266-0

Sánchez J, Zea S, Díaz J (1998) Patterns of octocoral and black coral distribution in the oceanic barrier reefcomplex of Old Providence island, southwestern Caribbean. Caribbean Journal of Science 34(3-4):250-264

Sellner K (1997) Physiology, ecology, and toxic properties of marine cyanobacteria blooms. Limnology and Oceanography 42(5 II):1089-1104

Sivonen K (1996) Cyanobacterial toxins and toxin production. Phycologia 35(SUPPL.):12-24

Smith J, Kuwabara J, Coney J, Flanagan K, Beets J, Brown D, Stanton F, Takabayashi M, DuPlessis S, Griesemer B, Barnes S, Turner J (2008) An unusual cyanobacterial bloom in Hawaii. Coral Reefs 27(4):851 doi 10.1007/ s00338-008-0417-0
Stielow S, Ballantine D (2003) Benthic cyanobacterial, Microcoleus lyngbyaceus, blooms in shallow, inshore Puerto Rican seagrass habitats, Caribbean sea. Harmful Algae 2(2):127-133 doi 10.1016/S1568-9883(03)00007-6

Thacker R, Nagle D, Paul V (1997) Effects of repeated exposures to marine cyanobacterial secondary metabolites on feeding by juvenile rabbitfish and parrotfish. Marine Ecology Progress Series 147(1-3):21-29

Thacker R, Paul V (2001) Are benthic cyanobacteria indicators of nutrient enrichment? Relationships between cyanobacterial abundance and environmental factors on the reef flats of Guam. Bulletin of Marine Science 69(2):497508

Thacker R, Paul V (2004) Morphological, chemical, and genetic diversity of tropical marine cyanobacteria Lyngbya spp. and Symploca spp. (Oscillatoriales). Applied and Environmental Microbiology 70(6):3305-3312 doi 10.1128/AEM.70.6.3305-3312.2004

Titlyanov E, Yakovleva I, Titlyanova T (2007) Interaction between benthic algae (Lyngbya bouillonii, Dictyota dichotoma) and scleractinian coral Porites lutea in direct contact. Journal of Experimental Marine Biology and Ecology 342(2):282-291 doi 10.1016/j.jembe.2006.11.007

Vermeij M, van Moorselaar I, Engelhard S, Hörnlein C, Vonk S, Visser P (2010) The effects of nutrient enrichment and herbivore abundance on the ability of turf algae to overgrow coral in the Caribbean. PLoS ONE 5(12):e14312 doi 10.1371/journal.pone.0014312

Vides M, Sierra-Correa P (2003) Atlas de Paisajes Costeros de Colombia. Instituto de Investigaciones Marinas y Costeras -INVEMAR- y Corporación Autónoma Regional y de Desarrollo Sostenible del Archipiélago de San Andrés, Old Providence y Santa Catalina -CORALINA-, Santa Marta, Colombia. $132 \mathrm{p}$

Vivas-Aguas L, Garay J, Espinosa L, Abdulazis P, Bent O, Guerrero T, Osorio L, Pomare A, Taylor J (2012) Calidad ambiental en las islas de San Andres, Old Providence y Santa Catalina. 62-72 p. In: CORALINA-INVEMAR. Gómez-López D, Segura-Quintero C, Sierra-Correa P, Garay-Tinoco J (eds) Atlas de la reserva de la Biósfera Seaflower, Archipiélago de San Andrés, Old Providence y Santa Catalina. Instituto de Investigaciones Marinas y Costeras "José Benito Vives de Andréis" -INVEMAR-, Corporación para el Desarrollo Sostenible del Archiépelago de San Andrés, Old Providence y Santa Catalina -CORALINA-, Santa Marta, Colombia, pp 180

Walker BK, Riegl B, Dodge RE (2008) Mapping Coral reef habitats in Southeast Florida using a combined technique approach. Journal of Coastal Research:1138-1150 doi 10.2112/06-0809.1

Watkinson A, O'Neil J, Dennison W (2005) Ecophysiology of the marine cyanobacterium Lyngbya majuscula (Oscillatoriaceae) in Moreton Bay, Australia. Harmful Algae 4(4):697-715 doi 10.1016/j.hal.2004.09.001 
Yamamuro M (1999) Importance of epiphytic cyanobacteria as food sources for heterotrophs in a tropical seagrass bed. Coral Reefs 18(3):263-271 doi 10.1007/s003380050191

Escala espacial de afloramientos de cianobacterias en la Isla de Old Providence, Caribe colombiano

Resumen. Los afloramientos de cianobacterias han incrementado en las zonas costeras de todo el mundo, favorecidos por el exceso de nutrientes y el aparente calentamiento global. Éstos tienen consecuencias negativas sobre los ecosistemas, comunidades y hábitats marinos. Aunque los reportes de estos eventos son frecuentes, la extensión y los hábitats afectados aún no han sido completamente caracterizados, lo cual limita las acciones de manejo. En este estudio examinamos la presencia, escala espacial y cobertura de afloramientos de cianobacterias en diferentes hábitats del complejo arrecifal de la isla de Old Providence, e identificamos los principales taxa que generan afloramientos. Las cianobacterias fueron registradas en cuatro ecosistemas, seis zonas geomorfológicas y nueve hábitats. Las cianobacterias bentónicas cubrieron entre el 18 y el $72 \%$ del sustrato en cinco hábitats, particularmente en el noroeste, este y parte sur de la isla. Tales afloramientos estuvieron conformados por consorcios complejos pertenecientes a los géneros Okeania, Lyngbya, Symploca, Phormidium, Oscillatoria o Spirulina. El afloramiento de cianobacterias planctónicas estuvo dominado por Trichodesmium y se desarrolló en la terraza prearrecifal (NO), tras un periodo de fuertes lluvias. Los resultados sugieren un nuevo estresor potencial para el complejo arrecifal de la isla. La investigación futura debería concentrarse en los factores ambientales que facilitan los afloramientos de cianobacterias y en el impacto local sobre los ecosistemas y sus servicios.

Palabras clave: cianobacterias; zonas geomorfológicas; hábitat; consorcio microbiano; sistema arrecifal; Caribe.
Zhang M, Duan H, Shi X, Yu Y, Kong F (2012) Contributions of meteorology to the phenology of cyanobacterial blooms: implications for future climate change. Water Research 46: 442-452 doi 10.1016/j.watres.2011.11.013

Escala espacial de afloramentos de cianobactérias na ilha Old Providence, Caribe colombiano

Resumo. Os afloramentos de cianobactérias têm aumentado em águas costeiras de todo o mundo, devido à entrada de nutrientes excessivos e também aparentemente ao aquecimento global. Estes afloramentos exercem efeitos negativos nos ecossistemas, comunidades e habitats marinhos. Embora os relatórios destes eventos sejam frequentes na literatura, a extensão e os hábitats atingidos não são completamente conhecidos, o que implica a restrição das ações de gestão. Neste estudo analisamos a presença, escala espacial e cobertura dos afloramentos de cianobactérias em diferentes habitats marinhos do complexo recifal da ilha Old Providence, e identificamos as principais taxas que geram afloramentos. As cianobactérias foram registradas em quatro ecossistemas, seis zonas geomorfológicas e nove hábitats. Durante os afloramentos bentônicos, as cianobactérias atingiram entre 18 a $72 \%$ da cobertura total em cinco habitats, particularmente no noroeste, este e sudeste da ilha. Tais afloramentos são consórcios complexos pertencentes aos géneros Okeania, Lyngbya, Symploca, Phormidium, Oscillatoria e Spirulina. O afloramento de cianobactérias planctônicas foi dominado por Trichodesmium e se desenvolveu no terraço prearrecifal da porção noroeste da ilha, depois de chuva intensa. Os resultados sugerem um novo "estressor" potencial para o complexo recifal da ilha. As investigações futuras devem se concentrar nos fatores ambientais que facilitam o afloramento e no seu impacto local nos ecossistemas e serviços.

Palavras-chave: cianobactérias; zonas geomorfológicas; habitat; consorcios microbianos; sistema de recife. 